\title{
Volumetric Investigations on Molecular Interactions of Glycine/L-alanine in Aqueous Citric Acid Solutions at Different Temperatures
}

\author{
Poonam Patyar $^{1} \cdot$ Gurpreet Kaur $^{1} \cdot$ Tarnveer Kaur $^{1}$
}

Received: 24 March 2018 / Accepted: 22 September 2018 / Published online: 19 November 2018

(c) The Author(s) 2018

\begin{abstract}
Apparent molar volumes $\left(\phi_{V}\right)$ of glycine/L-alanine in water and in aqueous citric acid (CA) solutions of varying concentrations, i.e. $(0.05,0.10,0.20,0.30,0.40$ and 0.50$) \mathrm{mol} \cdot \mathrm{kg}^{-1}$ were determined from density measurements at temperatures $T=(288.15,298.15,308.15$, 310.15 and 318.15$) \mathrm{K}$ and at atmospheric pressure. Limiting partial molar volumes $\left(\phi_{V}^{\mathrm{o}}\right)$ and their corresponding partial molar volumes of transfer $\left(\Delta_{\mathrm{tr}} \phi_{V}\right)$ have been calculated from the $\phi_{V}$ data. The negative $\Delta_{\mathrm{tr}} \phi_{V}$ values obtained for glycine/L-alanine from water to aqueous CA solutions indicate the dominance of hydrophilic-hydrophobic/hydrophobic-hydrophilic and hydrophobic-hydrophobic interactions over ion/hydrophilic-dipolar interactions. Further, pair and triplet interaction coefficients, i.e. $\left(V_{\mathrm{AB}}\right)$ and $\left(V_{\mathrm{ABB}}\right)$ along with hydration number $\left(n_{\mathrm{H}}\right)$ have also been calculated. The effect of temperature on the volumetric properties of glycine/L-alanine in water and in aqueous CA solutions has been determined from the limiting partial molar expansibilities $\left(\partial \phi_{V}^{\mathrm{o}} / \partial T\right)_{p}$ and their secondorder derivative $\left(\partial^{2} \phi_{V}^{\mathrm{o}} / \partial T^{2}\right)_{P}$. The apparent specific volumes $\left(v_{\phi}\right)$ for glycine and L-alanine tend to approach sweet taste behavior both in the presence of water and in aqueous CA solutions. The $v_{\phi}$ values for glycine/L-alanine increase with increase in concentration of CA at all temperatures studied. This reveals that CA helps in enhancing the sweet taste behavior of glycine/L-alanine which also supports the dominance of hydrophobic-hydrophobic interactions.
\end{abstract}

Keywords Hydration number - Interaction coefficients · Partial molar expansibilities · Partial molar volumes $\cdot$ Partial molar volumes of transfer $\cdot$ Apparent specific volumes

Electronic supplementary material The online version of this article (https://doi.org/10.1007/s1095 3-018-0829-6) contains supplementary material, which is available to authorized users.

Poonam Patyar

poonam_chem@yahoo.co.in

1 Department of Chemistry, Punjabi University, Patiala, Punjab 147 002, India 


\section{Introduction}

Amino acids are the building blocks of proteins, thus they are regarded as an ideal model for the study of protein functioning and their complex structure [1,2]. The functional properties of protein molecules depend upon their three dimensional structure which arises due to a particular sequence of amino acids (hereafter written as AA) in a polypeptide chain. All AAs exists as zwitterionic species in aqueous solutions [3], thus their thermodynamic properties in a variety of media can provide valuable information about the stability and denaturation of proteins [4-16]. Recently, Lomesh and Kumar [17, 18] have reported the volumetric and acoustic properties of glycine, diglycine, L-alanine and L-phenylalanine in water and in $0.1 \mathrm{~mol} \cdot \mathrm{kg}^{-1}$ aqueous citric acid at different temperatures. Further, a literature survey reveals that not much systematic data is available regarding the thermodynamic and transport properties of AA as a function of concentration in citric acid solutions at different temperatures.

Citric acid (CA) (2-hydroxy-1,2,3-propanetricarboxylic acid) is a tri-basic acid and common metabolite of plants and animals. It is an environmentally acceptable organic acid, used in food, beverages, $\mathrm{pH}$ adjustment in buffers, and pharmaceuticals (as an acidifier) $[19,20]$, and is known to increase the stability of proteins [13]. The presence of one hydroxyl and three carboxyl groups in CA provides effective chemical properties so that it can act as an important metabolite in the citric acid cycle (CAC) of all aerobic organisms [21]. It also acts as a precursor for the bio-synthesis of many compounds in CAC including AA [22]. Therefore, it is of great interest to investigate the molecular interactions of AA with CA which can influence the behavior and conformational stability of proteins. In light of the above facts, presently we report the apparent molar volumes $\left(\phi_{V}\right)$ of glycine/Lalanine (both are non-essential amino acids) in water and in aqueous CA solutions, $m_{\mathrm{c}}$ (molality of aqueous CA $) \approx(0.05,0.10,0.20,0.30,0.40$ and 0.50$) \mathrm{mol} \cdot \mathrm{kg}^{-1}$ at temperatures, $T=(288.15,298.15,308.15,310.15$ and 318.15$) \mathrm{K}$ and at atmospheric pressure, obtained from experimental densities. Partial molar volumes $\left(\phi_{V}^{\mathrm{o}}\right)$ calculated from $\phi_{V}$ data have been used to calculate partial molar volumes of transfer $\left(\Delta_{\mathrm{tr}} \phi_{V}\right)$, apparent specific volumes $\left(v_{\phi}\right)$, pair $\left(V_{\mathrm{AB}}\right)$ and triplet $\left(V_{\mathrm{ABB}}\right)$ interaction coefficients, partial molar expansibilities $\left(\partial \phi_{V}^{\mathrm{o}} / \partial T\right)_{p}$, their second order derivatives $\left(\partial^{2} \phi_{V}^{\mathrm{o}} / \partial T^{2}\right)_{p}$ and hydration number $\left(n_{\mathrm{H}}\right)$. The volumetric behavior of glycine in aqueous CA solutions (present work) are compared with glycine in aqueous succinic acid (SA) solutions, reported earlier from our laboratory [23].

\section{Experimental Section}

\subsection{Chemicals Used}

Glycine $\left(\mathrm{C}_{2} \mathrm{H}_{5} \mathrm{NO}_{2}\right)$, L-alanine $\left(\mathrm{C}_{3} \mathrm{H}_{7} \mathrm{NO}_{2}\right)$ and citric acid $\left(\mathrm{C}_{6} \mathrm{H}_{8} \mathrm{O}_{7}\right)$ of analytical grade with mass fraction purity $\geq 99 \%$ were procured from S. D. Fine Chemical Ltd. (SDFCL), India. Specifications of the chemicals used are given in Table 1. All the chemicals were used without any further purification; however, they were dried in a vacuum oven for $24 \mathrm{~h}$ at $T=318.15 \mathrm{~K}$, and then kept in a vacuum desiccator over anhydrous $\mathrm{CaCl}_{2}$ prior to their use. 


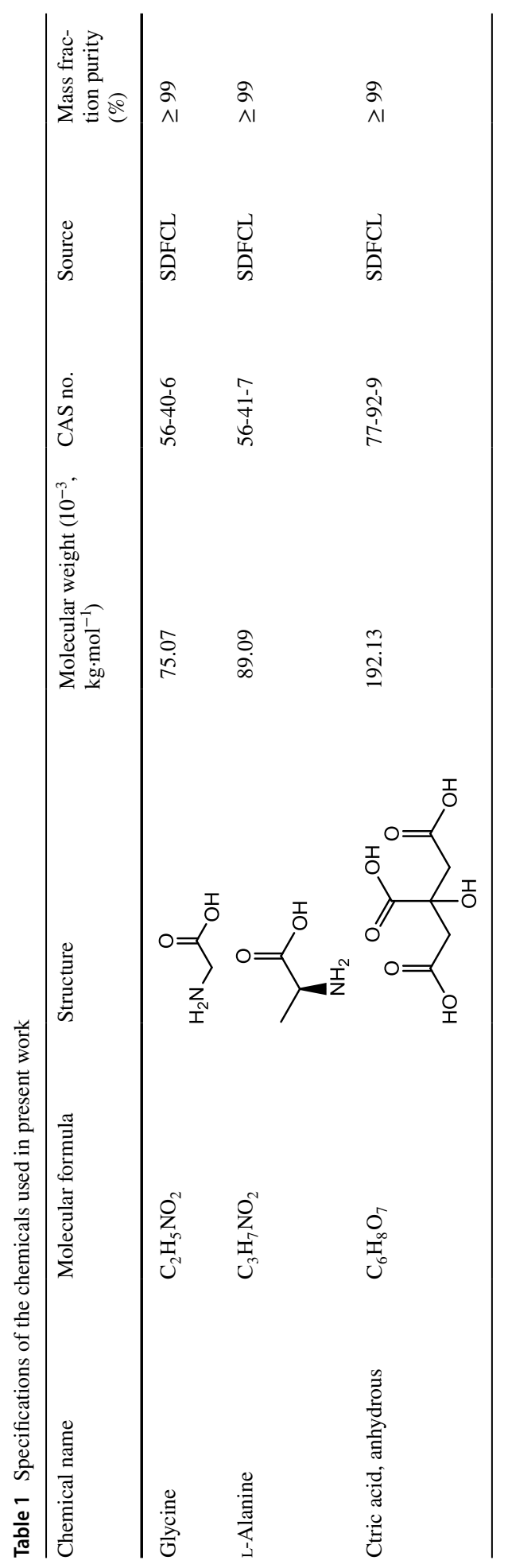


Deionized, double distilled and degassed water with specific conductance $<1 \times 10^{-4} \mathrm{~S} \cdot \mathrm{m}^{-1}$ was used to prepare all the solutions. The pHs of the experimental solutions were checked using a $\mathrm{pH}$ meter (Systronics digital $\mathrm{pH}$ meter-335, India). The standard deviation obtained for the whole set of experimental data is $\pm 0.02 \mathrm{pH}$ unit. Accuracy in $\mathrm{pH}$ measurements was checked by calibrating the $\mathrm{pH}$ meter using standard buffer solutions of $\mathrm{pH} 7.00$ and $\mathrm{pH} 9.20$. The $\mathrm{pHs}$ of the stock solutions, i.e. at all concentrations of aqueous citric acid solutions, lie between 2.08 and 2.44, in the case of glycine in aqueous citric acid solutions the pHs lie from 1.96 to 3.61 and for L-alanine in aqueous citric acid solutions it varies from 1.99 to 3.94. Solutions were prepared on the molality basis using a Citizen CY-204 balance having a precision of $\pm 0.1 \mathrm{mg}$. The overall uncertainty in molality was estimated to be $<5 \times 10^{-3} \mathrm{~mol} \cdot \mathrm{kg}^{-1}$. Solution densities were measured using a vibrating-tube digital density meter (DMA $4500 \mathrm{M}$ from Anton Paar, Austria). The sensitivity of the instrument corresponds to a precision in density measurements of $\pm 1 \times 10^{-2} \mathrm{~kg} \cdot \mathrm{m}^{-3}$ and accuracy of $\pm 5 \times 10^{-2} \mathrm{~kg} \cdot \mathrm{m}^{-3}$, respectively. The density meter has a built in thermostat to maintain the desired temperatures within $\pm 0.01 \mathrm{~K}$ and was calibrated with double distilled and degassed water before each series of experiments. The performance of the density meter was checked by measuring the densities of aqueous sodium chloride $(\mathrm{NaCl})$ solutions, which agree well with the literature values [24] as shown in Fig. 1.

\section{Results and Discussion}

\subsection{Volumetric Properties}

The apparent molar volumes $\left(\phi_{\mathrm{V}}\right)$ of glycine and L-alanine in water and in varying concentrations of aqueous CA solutions were calculated from experimental solution densities $(\rho)$ at temperatures $T=(288.15,298.15,308.15,310.15$ and 318.15$) \mathrm{K}$ and at atmospheric pressure, by employing the following equation:

$$
\phi_{V}=M / \rho-\left[1000\left(\rho-\rho_{\mathrm{o}}\right)\right] / m_{\mathrm{A}} \rho \rho_{\mathrm{o}}
$$

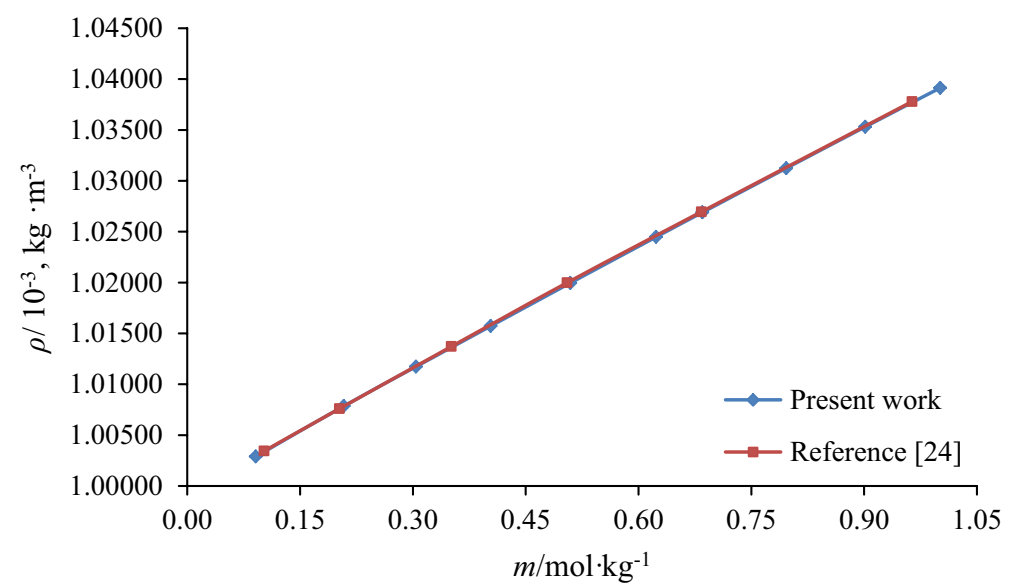

Fig. 1 Representative plots of densities $(\rho)$ versus molality $(m)$ : (blue filled square, present work; red filled square, literature values [24] of $\mathrm{NaCl}$ solutions at 288.15 K (Color figure online) 
where $M\left(\mathrm{~kg} \cdot \mathrm{mol}^{-1}\right)$ is the molar mass of the glycine/L-alanine, $m_{\mathrm{A}}\left(\mathrm{mol} \cdot \mathrm{kg}^{-1}\right)$ is the molality of glycine/L-alanine, $\rho_{\mathrm{o}}$ and $\rho$ are the densities of the solvent (water or water $+\mathrm{CA}$ ) and solution (water $+\mathrm{CA}+$ glycine/L-alanine), respectively. The $\phi_{V}$ values of glycine/L-alanine along with $\rho_{\mathrm{o}}$ and $\rho$ as a function of molality, in water and in aqueous CA solutions at different temperatures, are summarized in Table 2. The standard uncertainty in the apparent molar volume due to molality $\mathrm{u}(m)$ and density $\mathrm{u}(\rho)$ has been calculated and is $(\leq 0.0960$ and $\leq 1.611 \times 10^{-6} \mathrm{~m}^{3} \cdot \mathrm{mol}^{-1}$ ), respectively. Representative plots of $\phi_{V}$ values for the presently studied systems (i.e. glycine, L-alanine and citric acid in water) at $T=288.15 \mathrm{~K}$ agree well with earlier reported data [25-34] and are shown in Figs. 2, 3 and 4. The values reported by the authors $[25,33]$ are higher (at lower concentrations) than to our present results as well as with the other literature data. (The standard uncertainty in molality, $\mathrm{u}(\mathrm{m})$ and apparent molar volume, $\mathrm{u}\left(\phi_{V}\right)$ of (succinic acid + glycine) system are $\leq 2.21 \times 10^{-4}$ $\mathrm{mol} \cdot \mathrm{kg}^{-1}$ and $(0.03-0.65) \times 10^{-6} \mathrm{~m}^{3} \cdot \mathrm{mol}^{-1}$, respectively).

The variation of $\phi_{V}$ versus $m_{\mathrm{A}}$ for glycine/L-alanine in water and in different concentrations of aqueous CA solutions at $288.15 \mathrm{~K}$ are shown in Figs. 5 and 6, respectively (representative plots only). It is observed from Figs. 5 and 6 that the $\phi_{V}$ values of glycine/L-alanine in aqueous CA solutions vary almost linearly with increases in AA concentration as well as with temperature, whereas these values decrease with increases in the concentration of aqueous CA in these solutions. The higher $\phi_{V}$ values obtained for glycine/L-alanine in water indicate that strong solute-solvent interactions exist between glycine/L-alanine and water. In fact, strong interactions of the three carboxyl groups and one hydroxyl group of CA with water via hydrogen bonds leads to the higher $\phi_{V}$ values, however the hydrophobic group in SA [23] reduces its ability to form strong hydrogen bonds with water, thus resulting in smaller $\phi_{V}$ values (Fig. 7a). The basic structures of citric acid (CA), succinic acid (SA), glycine and L-alanine are given in Scheme 1.

Solute-solute interactions are eliminated at infinite dilution and hence the apparent molar volume $\left(\phi_{V}\right)$ becomes equal to the limiting partial molar volume $\left(\phi_{V}^{\mathrm{o}}\right)$. The $\phi_{V}^{\mathrm{o}}$ values have been evaluated by least-squares fitting of the following equation to the corresponding data:

$$
\phi_{V}=\phi_{V}^{\mathrm{o}}+S_{V} m_{\mathrm{A}}
$$

where $\phi_{V}^{\mathrm{o}}$ provides a measure of solute-solvent interactions, and the experimental slope $S_{\mathrm{v}}$ provides information regarding solute-solute interactions [28]. $\phi_{V}^{\mathrm{o}}$ and $S_{V}$ values of glycine/L-alanine in water and in aqueous CA solutions at different temperatures are listed in Table 3. The standard uncertainty of the limiting partial molar volumes has been found to be $\leq 0.07 \times 10^{-6} \mathrm{~m}^{3} \cdot \mathrm{mol}^{-1}$. The $\phi_{V}^{\mathrm{o}}$ values of glycine/L-alanine in water agree well with the literature values at different temperatures and are shown in Figs. 8 and 9 [8, 23, $26-28,30,35,36]$. Table 3 shows that the $\phi_{V}^{\circ}$ values are higher for L-alanine in water and in aqueous CA solutions compared to glycine, as expected, which is due to the increase in the molar mass of L-alanine. The magnitude of the $\phi_{V}^{o}$ values is higher than the $S_{\mathrm{v}}$ values, which suggests that the extent of solute-solvent interactions is greater compared to solute-solute interactions. Moreover, the $\phi_{V}^{\mathrm{o}}$ values decrease with increase in aqueous CA concentration whereas they increase with increasing temperature. The decrease in $\phi_{V}^{\mathrm{o}}$ values with increasing concentration of CA may be attributed to the disruption of side group hydration by that of the charged end groups (a similar explanation has been given by Wang et al. [37], which supports our results for the $\phi_{V}^{\mathrm{o}}$ values), whereas the increase in $\phi_{V}^{\mathrm{o}}$ values of glycine/L-alanine in CA solutions with increase in temperature may lead to reduction of the electrostriction around the zwitterions [38]. Also, at higher temperatures, solvent from the secondary solvation layer of glycine/L-alanine is released into the bulk of solvent which results in the expansion of the solution and leads to higher $\phi_{V}^{0}$ values [39]. 


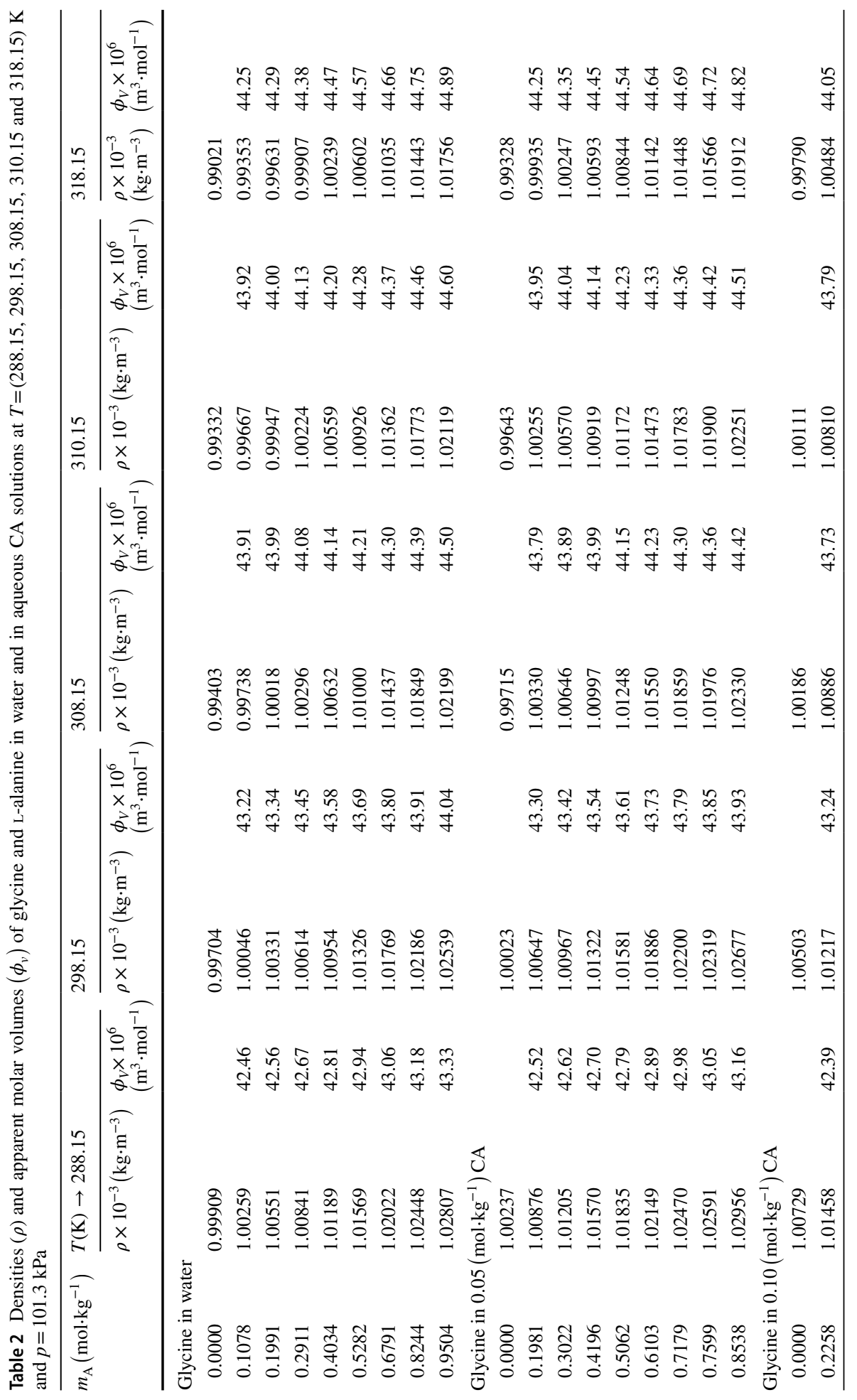




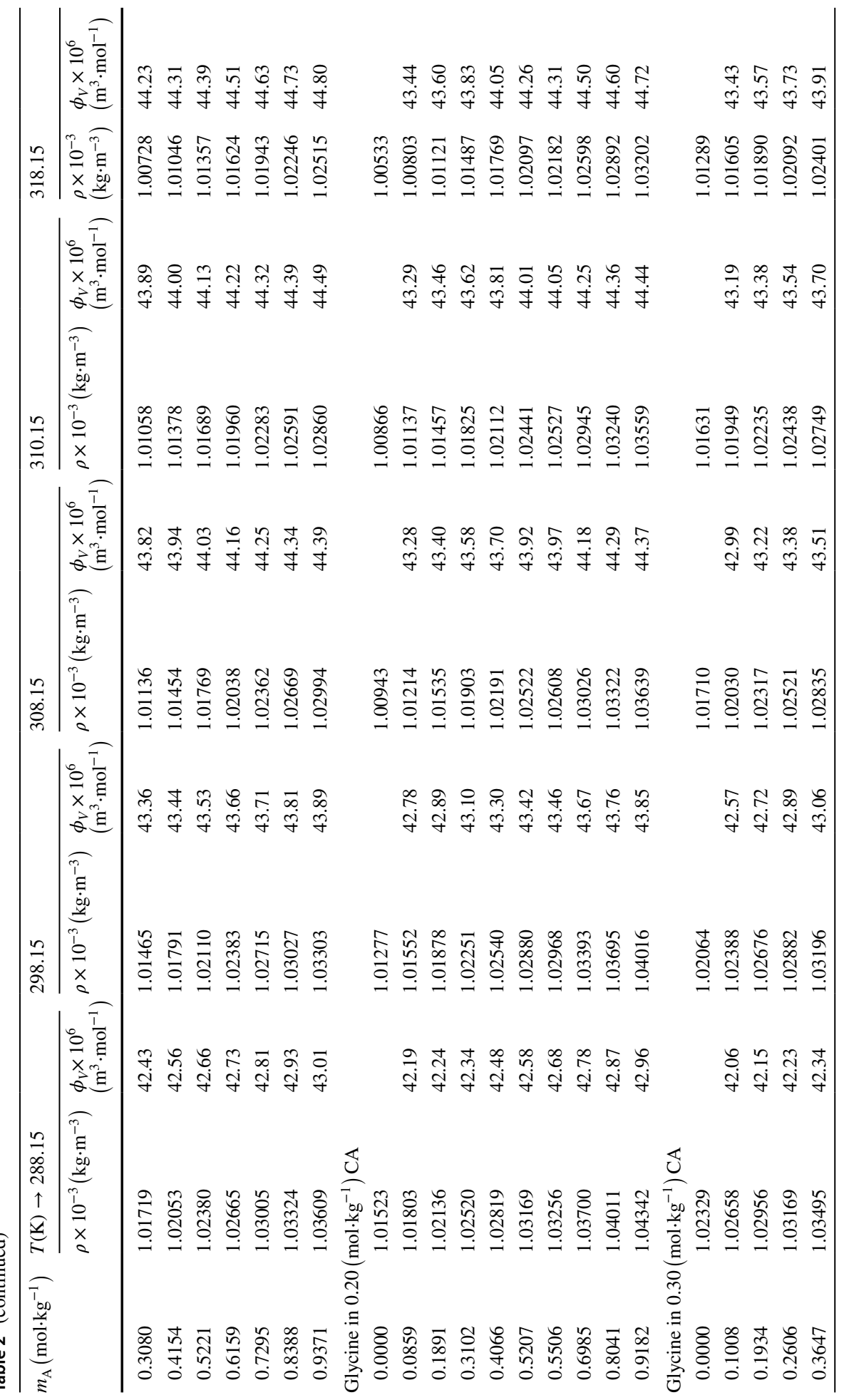




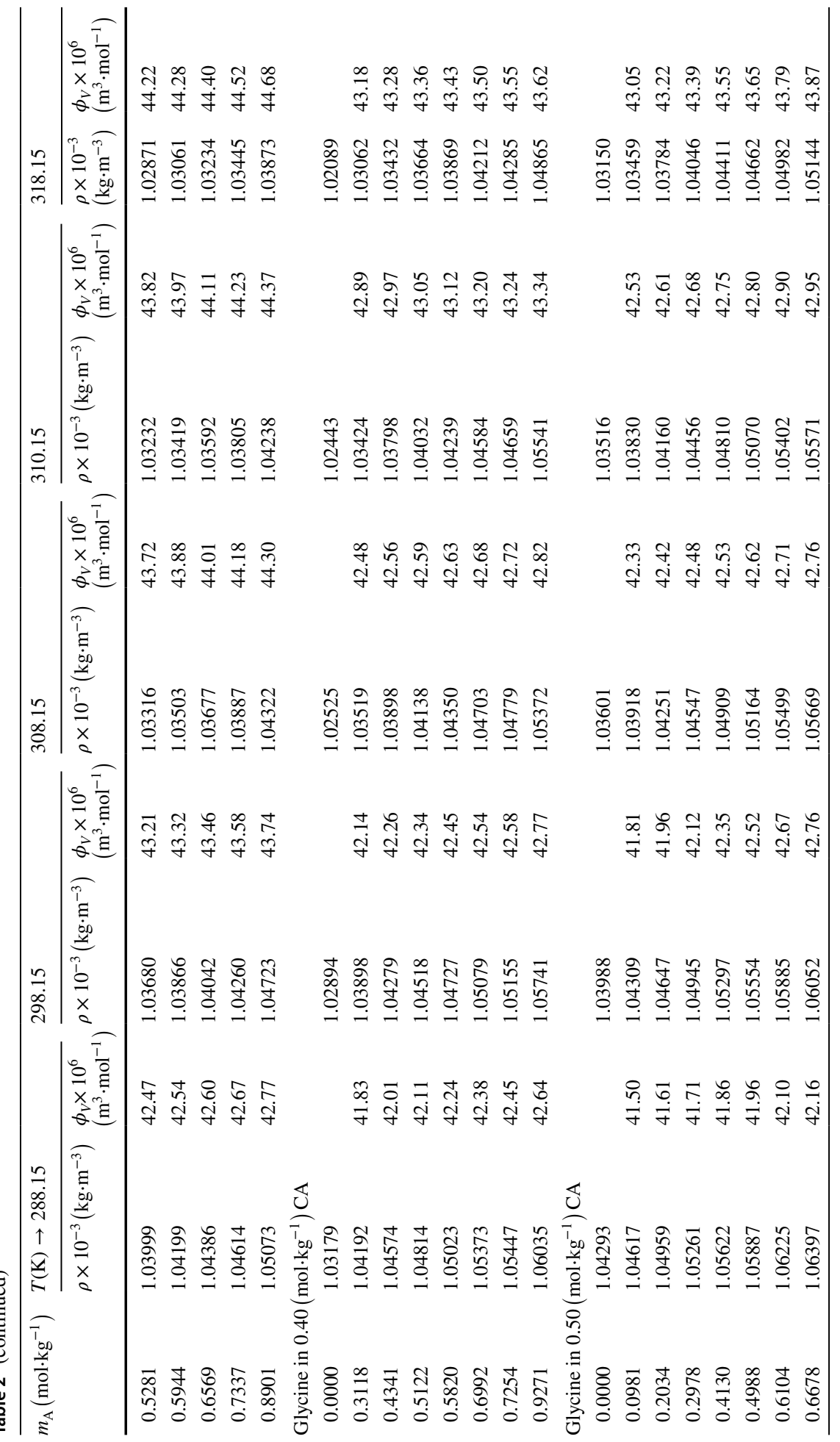




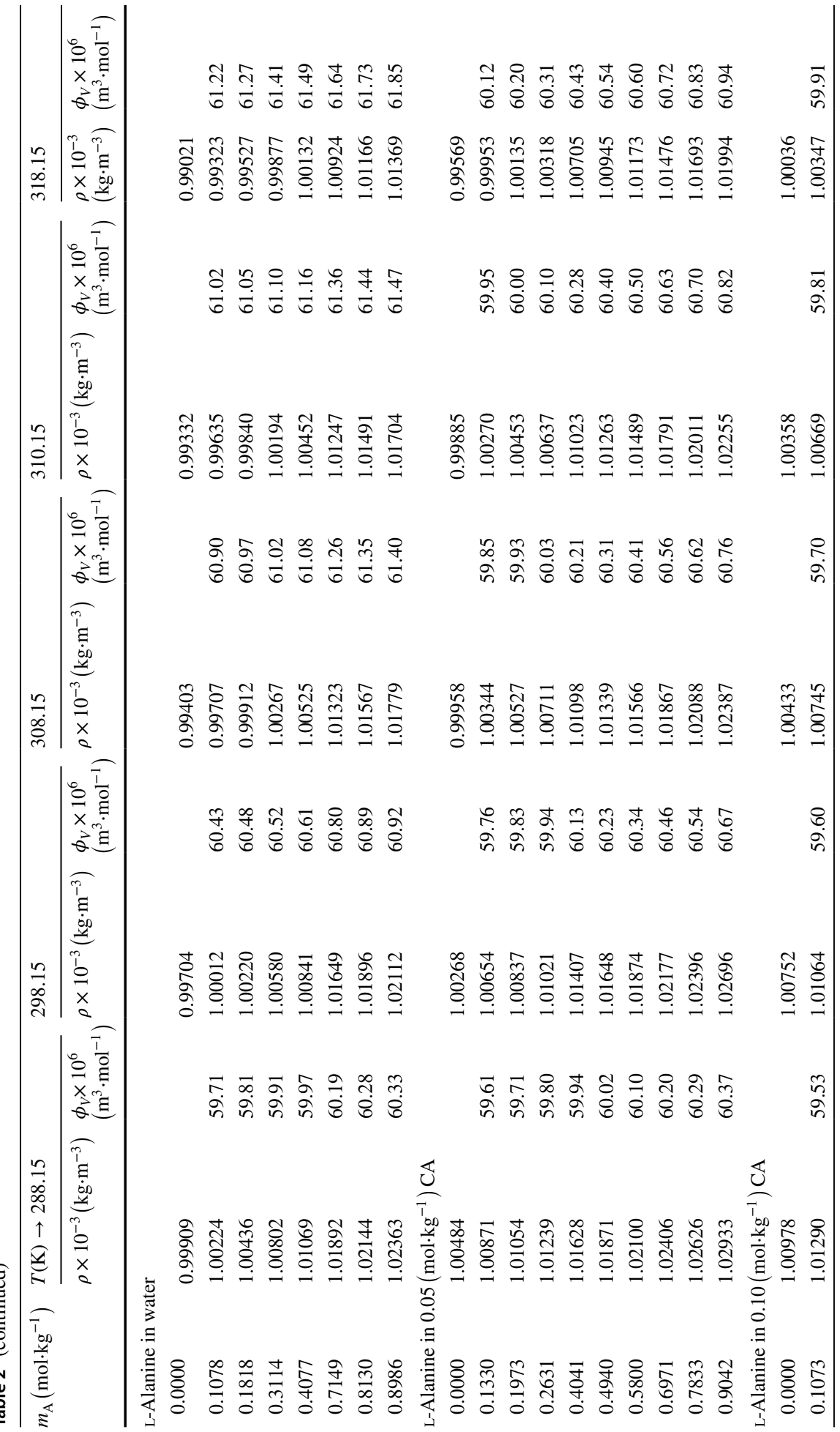




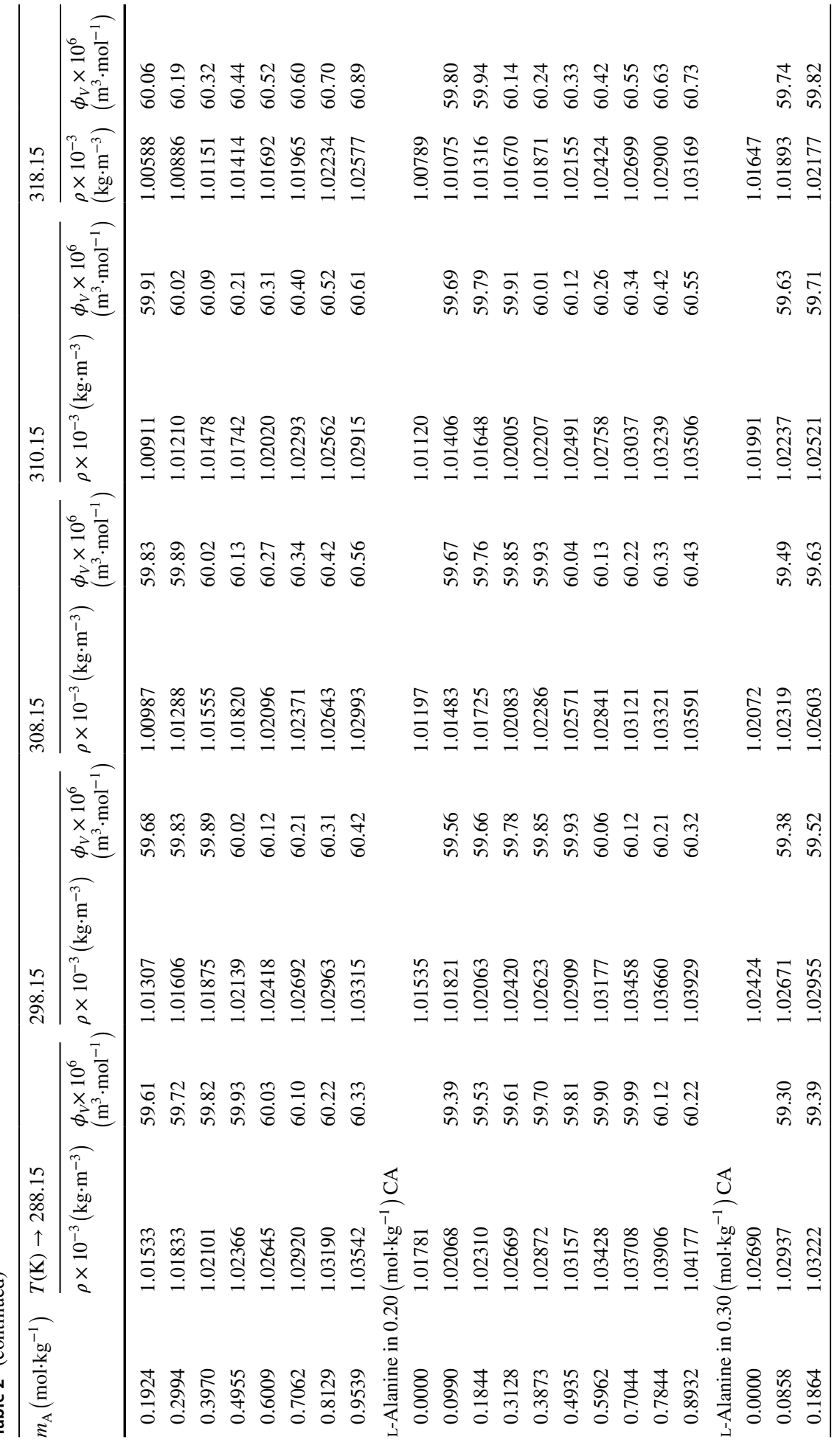




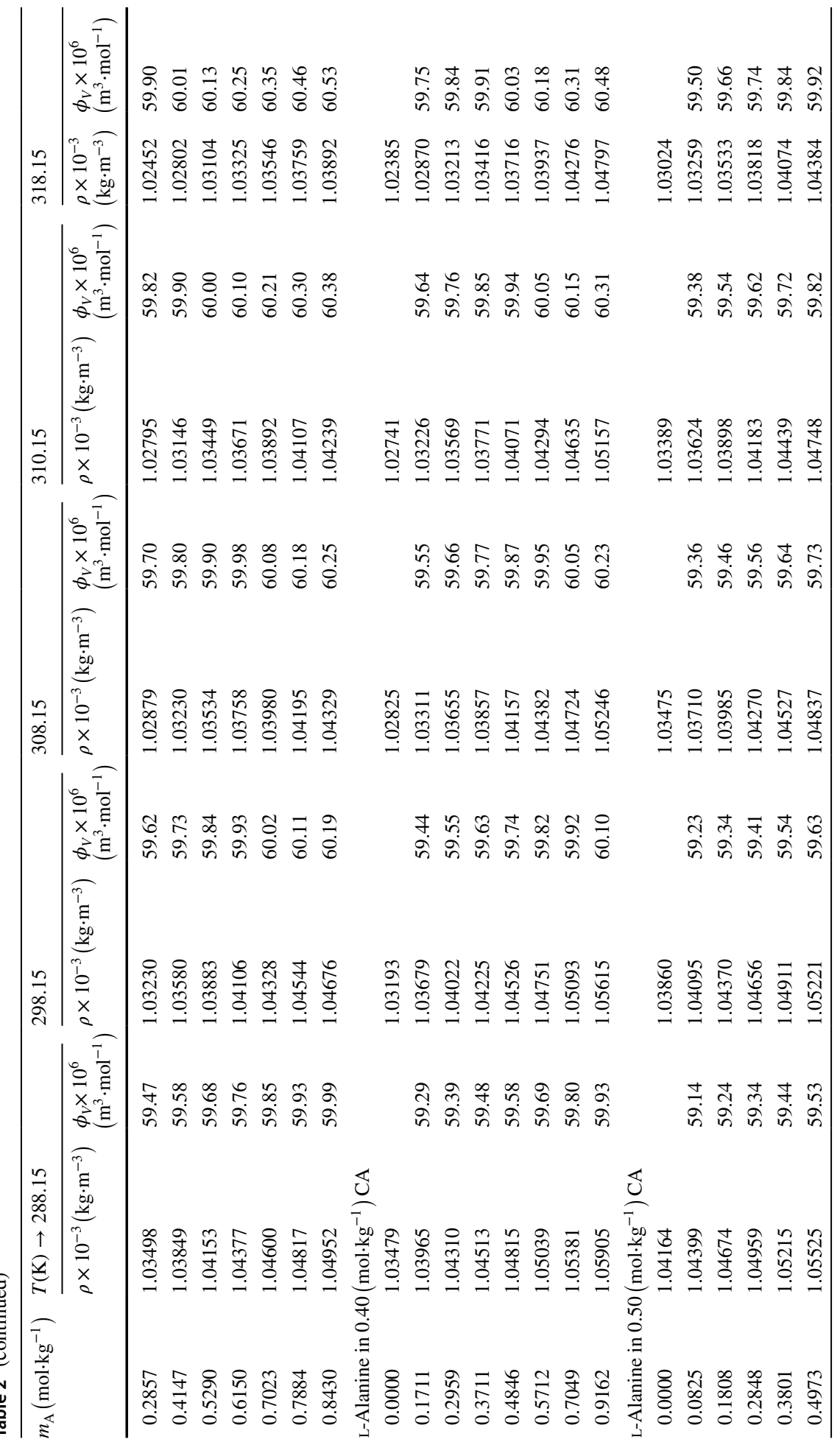




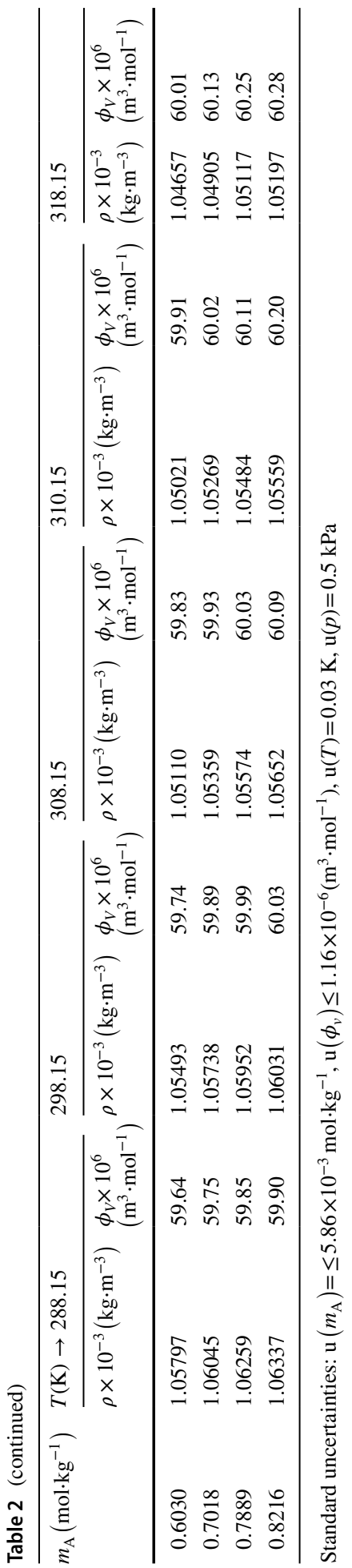




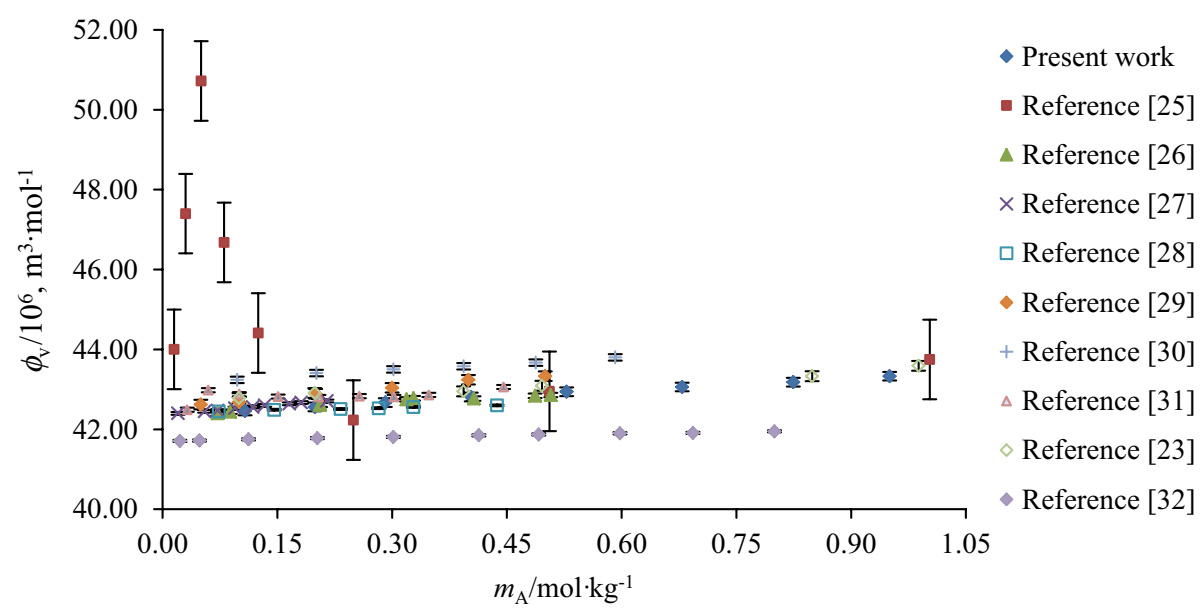

Fig. 2 Representative plots of apparent molar volumes $\left(\phi_{V}\right)$ versus molality $\left(m_{\mathrm{A}}\right)$ of glycine in water at $288.15 \mathrm{~K}$ : (red filled square, present work and blue filled square, literature values [23, 25-32]) (Color figure online)

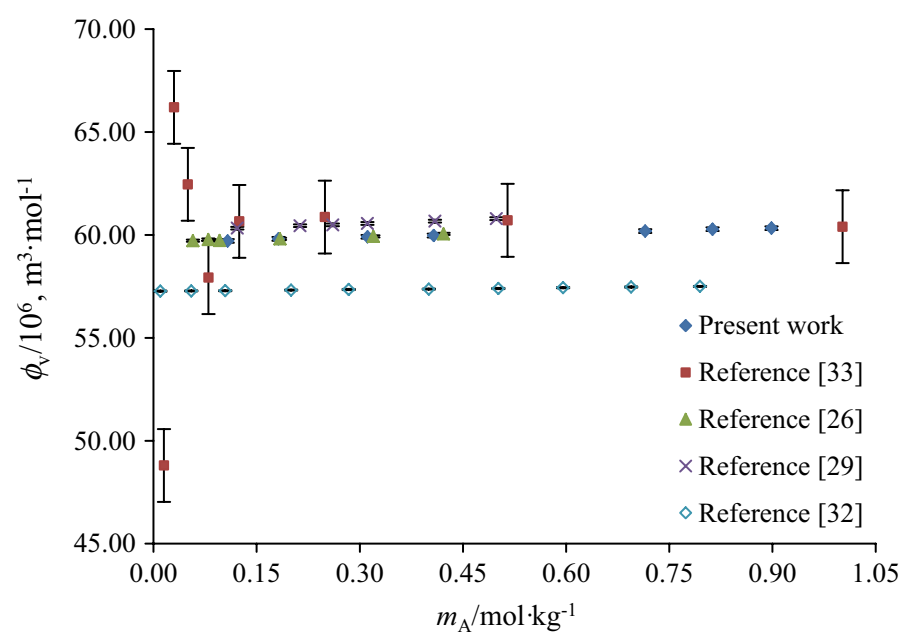

Fig. 3 Representative plots of apparent molar volumes $\left(\phi_{V}\right)$ versus molality $\left(m_{\mathrm{A}}\right)$ of L-alanine in water at $288.15 \mathrm{~K}$ : red filled square, present work and blue filled square, literature values [26, 29, 32, 33] (Color figure online)

Comparison of $\phi_{V}$ and $\phi_{V}^{\mathrm{o}}$ values of glycine in CA (present work) with previously reported data of glycine in SA [23] reveals that the magnitudes of $\phi_{V}$ and $\phi_{V}^{\mathrm{o}}$ values for glycine-CA are higher than for glycine-SA (Figs. 7(a), (b), 10). As discussed earlier, the higher magnitudes for glycine in CA solutions are again attributed to the presence of additional hydrophilic groups ( $-\mathrm{OH}$ and $-\mathrm{COOH}$ in $\mathrm{CA}$ ) which leads to stronger interactions between glycine/L-alanine and CA, i.e. it is due to the formation of hydrogen bonds (Scheme 2) [40]. Further, the effect of $\mathrm{pH}$ on speciation and charge distribution of these systems involves the stronger interaction among citrate ion and the ionized ammonium group. The amino and carboxyl groups of glycine/L-alanine dissociate 


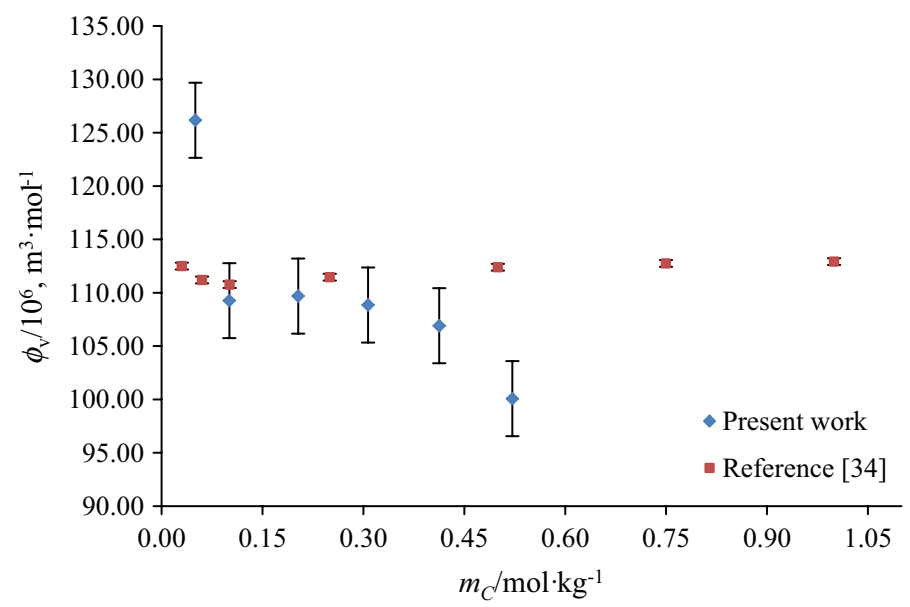

Fig. 4 Representative plots of apparent molar volumes $\left(\phi_{V}\right)$ versus molality $\left(m_{\mathrm{c}}\right)$ of citric acid in water at 288.15 K: red filled square, Present work and blue filled square literature values [34] (Color figure online)

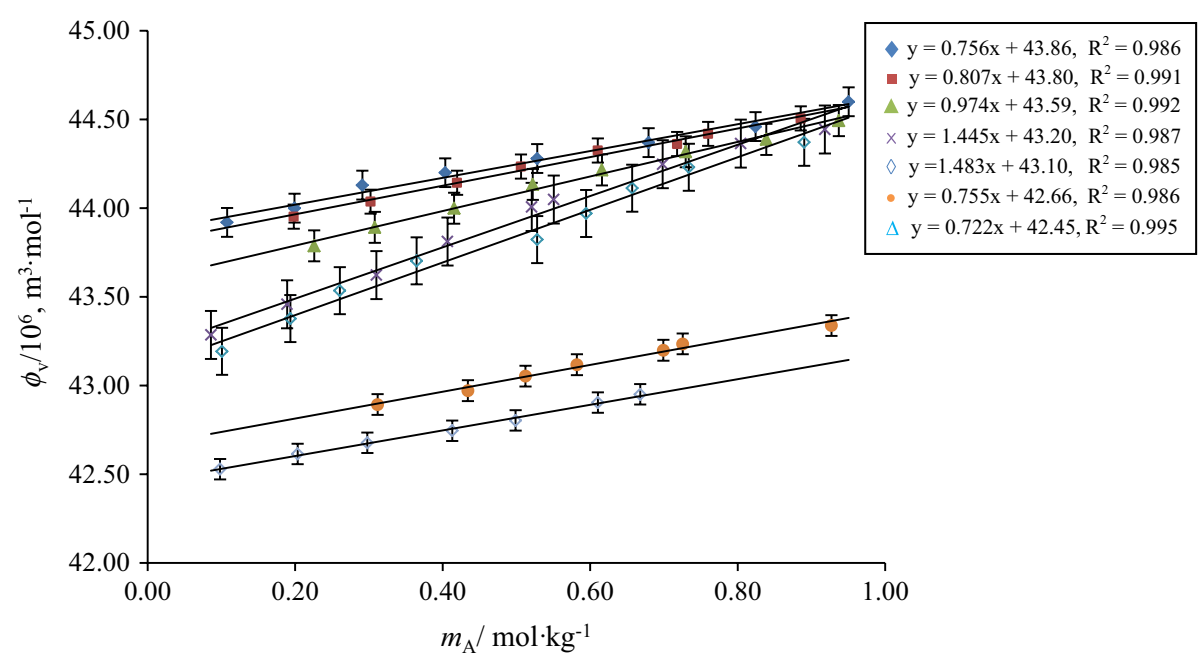

Fig. 5 Representative plots of apparent molar volumes $\left(\phi_{V}\right)$ versus molality $\left(m_{\mathrm{A}}\right)$ of glycine in water and in different concentrations of aqueous CA solutions at $288.15 \mathrm{~K}:\left(m_{\mathrm{c}}\right)=$ blue filled diamond, water; red filled square, 0.05; Green filled triangle, 0.10; Violet multiply symbol, 0.20; blue open diamond, 0.30; orange filled circle, 0.40 ; blue open triangle, $0.50 \mathrm{~mol} \cdot \mathrm{kg}^{-1}$ (Color figure online)

in aqueous citric acid solutions and form negatively and positively charged ions (i.e., ${ }^{+} \mathrm{NH}_{3}-\left(\mathrm{CH}\left(\mathrm{H} / \mathrm{CH}_{3}\right)-\mathrm{COO}^{-}\right)$. Dissociation of citric acid in aqueous solutions [19], i.e. the negatively and positively charged ions, results in the formation of new species in aqueous solutions as:

$$
\begin{aligned}
\mathrm{NH}_{3} \mathrm{RCOO}^{-} & \rightleftharpoons \mathrm{NH}_{2} \mathrm{RCOO}^{-}+\mathrm{H}^{+} \\
\mathrm{H}_{3} \mathrm{Cit}^{-} & \rightleftharpoons \mathrm{H}_{2} \mathrm{Cit}^{-}+\mathrm{H}^{+}
\end{aligned}
$$




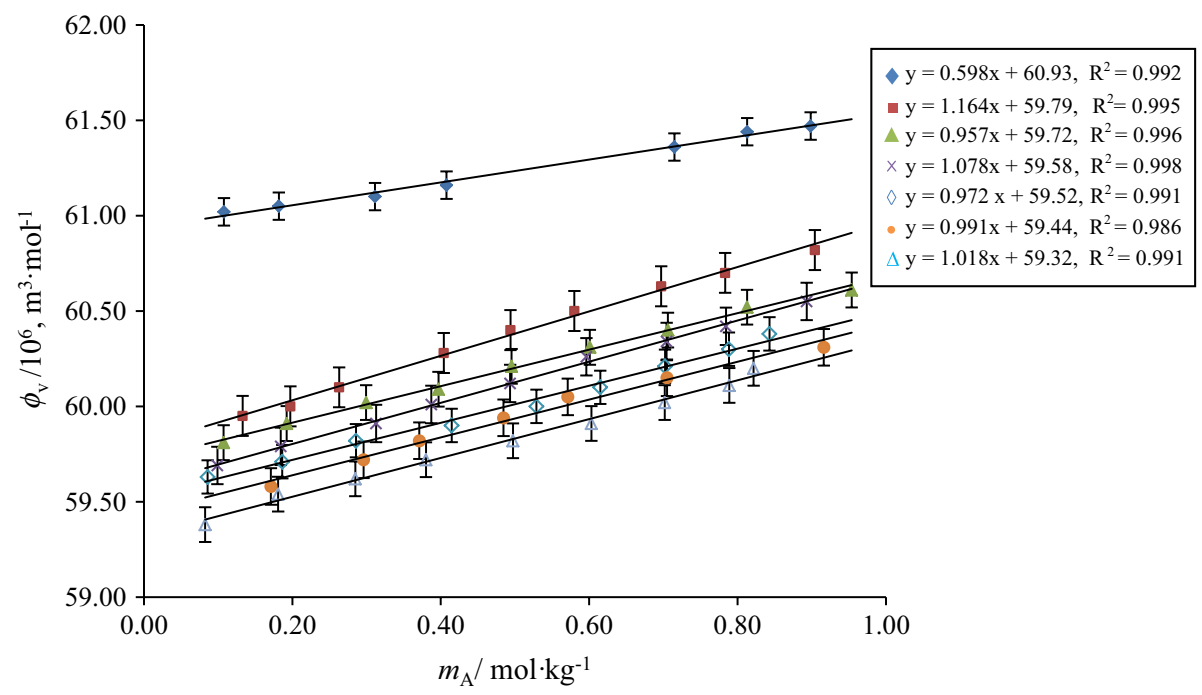

Fig. 6 Representative plots of apparent molar volumes $\left(\phi_{v}\right)$ versus molality $\left(m_{\mathrm{A}}\right)$ of L-alanine in water and in different concentrations of aqueous CA solutions at $288.15 \mathrm{~K}:\left(m_{\mathrm{c}}\right)=$ blue filled diamond, water; red filled square, 0.05; Green filled triangle, 0.10; Violet multiply symbol, 0.20; blue open diamond, 0.30; orange filled circle, 0.40 ; blue open triangle, $0.50 \mathrm{~mol} \cdot \mathrm{kg}^{-1}$ (Color figure online)

$$
\begin{aligned}
\mathrm{H}_{2} \mathrm{Cit}^{-} & \rightleftharpoons \mathrm{H}^{+}+\mathrm{HCit}^{2-} \\
\mathrm{H}_{2} \mathrm{O} & \rightleftharpoons \mathrm{H}^{+}+\mathrm{OH}^{-}
\end{aligned}
$$

Partial molar volumes of transfer $\left(\Delta_{\text {tr }} \phi_{V}\right)$ of glycine/L-alanine from water to aqueous CA solutions at infinite dilution have been calculated by using the following equation:

$$
\left.\Delta_{\text {tr }} \phi_{v}(\text { water } \rightarrow \text { aqueous CA solutions })=\phi_{V}^{\mathrm{o}}(\text { in aqueous CA solutions })-\phi_{V}^{\mathrm{o}} \text { (in water }\right)
$$

The $\Delta_{\text {tr }} \phi_{v}$ values reported in Table S1 (supplementary material) are negative and decrease with increase in the concentration of aqueous CA solutions at the studied temperatures (Figs. 11 and 12). The standard uncertainty in $\Delta_{\text {tr }} \phi_{V}$ values has been found to be $\leq 0.07 \times 10^{-6} \mathrm{~m}^{3} \cdot \mathrm{mol}^{-1}$. The possible interactions which may exist between ternary system (i.e. glycine/L-alanine + aqueous CA) (Scheme 2) can be categorized as: (1) ion/hydrophilic-dipolar interactions between $\left(3 \mathrm{COO}^{-},-\mathrm{OH}\right)$ of $\mathrm{CA}$ and $\left(\mathrm{NH}_{3}{ }^{+}, \mathrm{COO}^{-}\right)$zwitterions of glycine/L-alanine, (2) hydrophilic-hydrophobic interactions between the $\left(3 \mathrm{COO}^{-},-\mathrm{OH}\right)$ groups of CA with the non-ionic group of glycine/L-alanine, (3) hydrophobic-hydrophilic interactions between the non-ionic group of CA and zwitterionic groups of glycine/Lalanine, and (4) hydrophobic-hydrophobic group interactions between the alkyl chains of glycine/L-alanine and CA. According to the co-sphere overlap model [41], the overlap of the hydration co-spheres of hydrophilic and ionic parts (type 1) results in positive $\Delta_{\text {tr }} \phi_{V}$ values, whereas interactions of type 2,3 and 4 result in negative transfer volumes. The presently observed negative $\Delta_{\text {tr }} \phi_{V}$ values for glycine/L-alanine in aqueous CA solutions at different temperatures suggest the dominance of hydrophilic-hydrophobic and hydrophobic-hydrophobic interactions over ion/hydrophilic-dipolar interactions. The greater magnitude of $\Delta_{\mathrm{tr}} \phi_{V}$ observed in the case of L-alanine in CA may be attributed to the presence of 


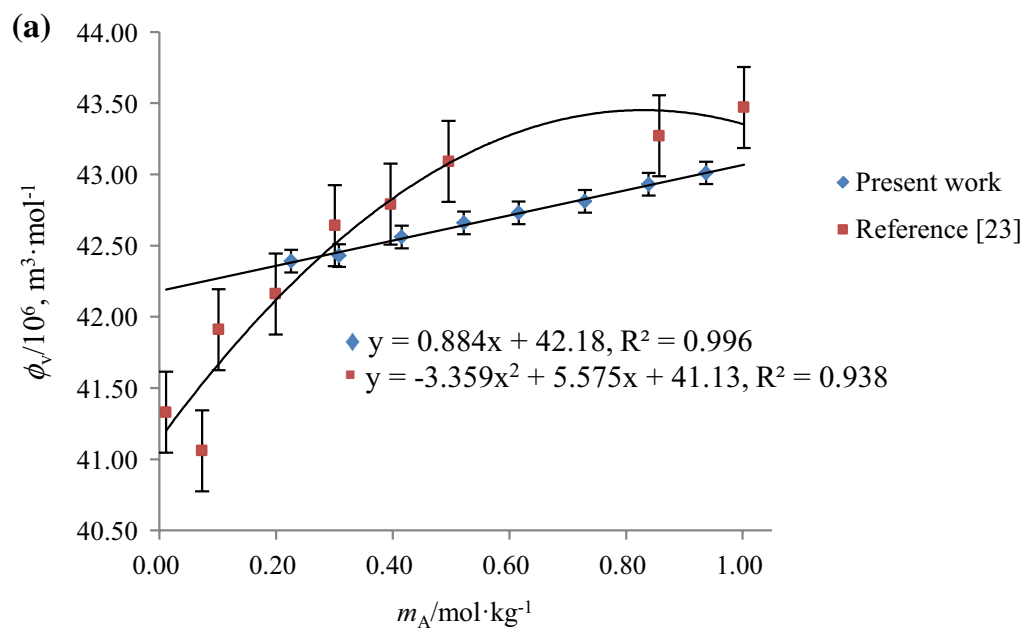

(b)

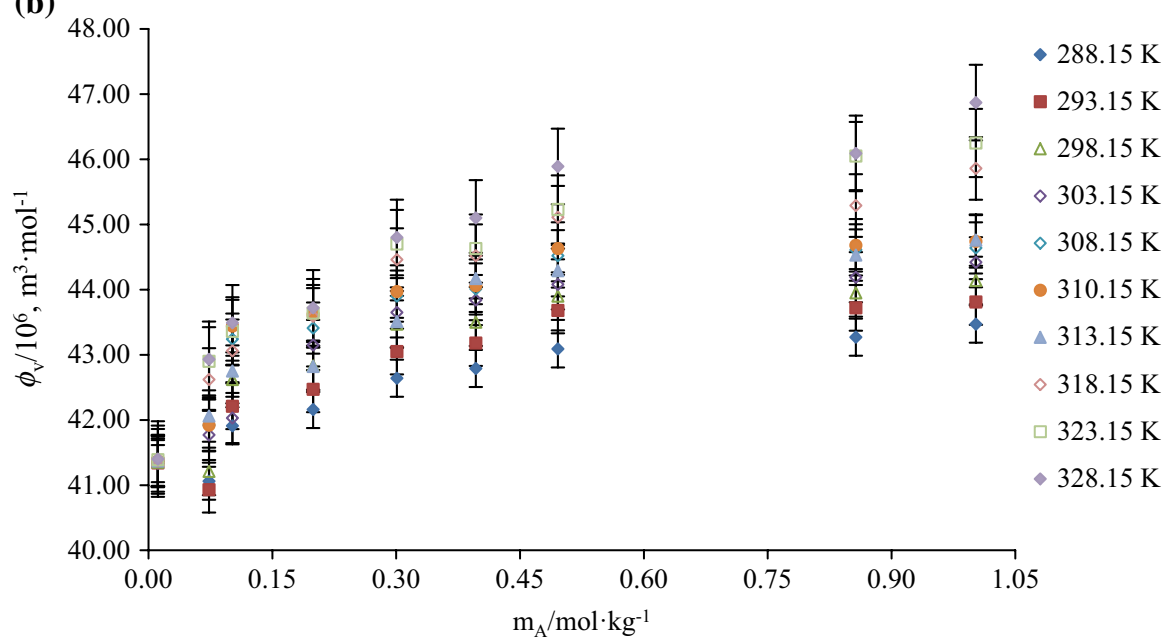

Fig. 7 (a) Representative plots of apparent molar volumes $\left(\phi_{V}\right)$ versus molality $\left(m_{\mathrm{A}}\right)$ of glycine in: blue filled diamond, $0.10 \mathrm{~mol} \cdot \mathrm{kg}^{-1}$ aqueous CA solutions and red filled square, $0.10 \mathrm{~mol} \cdot \mathrm{kg}^{-1}$ in aqueous succinic acid (abbreviated as SA) solutions at $288.15 \mathrm{~K}$. b Plots of apparent molar volumes $\left(\phi_{V}\right)$ of glycine versus molality $\left(m_{\mathrm{A}}\right)$ in $0.10 \mathrm{~mol} \cdot \mathrm{kg}^{-1}$ aqueous succinic acid solutions (abbreviated as SA) at different temperatures, $T=(288.15-328.15) \mathrm{K}$ (Color figure online)

an alkyl group in L-alanine which further strengthens the view that hydrophobic-hydrophobic interactions are dominating in the case of L-alanine-CA (i.e. type 4 interactions).

The magnitude of $\phi_{V}^{\mathrm{o}}$ values of glycine/L-alanine in CA can also be explained by considering the modified equation of Shahidi and Farrell [42],

$$
\phi_{V}^{\mathrm{o}}=V_{v, \mathrm{w}}+V_{\text {void }}-V_{\text {shrinkage }}
$$

where $V_{v, \mathrm{w}}$ is the van der Waal's volume, $V_{\text {void }}$ is the volume associated with voids, and $V_{\text {shrinkage }}$ is the volume due to shrinkage that arises from electrostriction of solvent molecules caused by hydrophilic groups present in the solute. Assuming that $V_{v, \mathrm{w}}$ and $V_{\text {void }}$ are not significantly affected by the presence of CA, then the negative $\Delta_{\text {tr }} \phi_{V}$ values may 


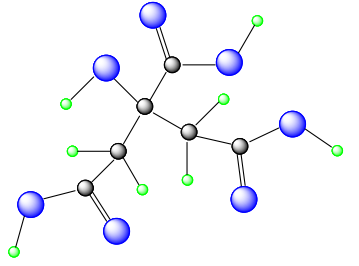

(a)

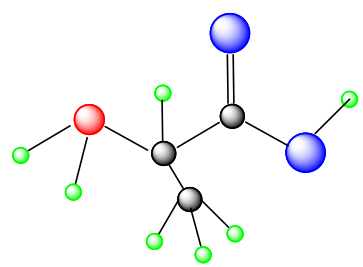

(d)

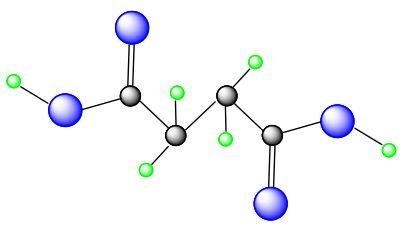

(b)

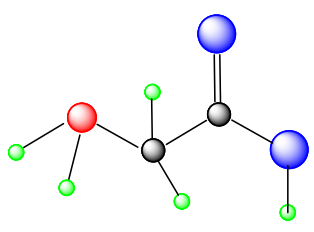

(c)

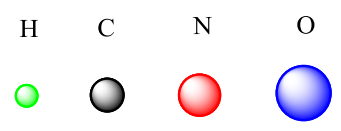

Scheme 1 Basic structures of (a) citric acid, (b) succinic acid, (c) glycine and (d) L-alanine

be attributed to enhanced electrostriction in the vicinity of charged centers of zwitterions which results in an increase of $V_{\text {shrinkage }}$. Further, it is observed from Table S1 that the $\Delta_{\text {tr }} \phi_{V}$ values for glycine in CA are higher in contrast to glycine in SA solutions [23], which is attributed to the presence of additional hydrophilic groups in CA that leads to the formation of strong hydrogen bonding with glycine (Scheme 2).

The McMillan-Mayer theory of solutions [43, 44] permits the formal separation of the effects due to the interactions between two or more solutes. According to this theory, the pair and triplet interaction coefficients $\left(V_{\mathrm{AB}}\right)$ and $\left(V_{\mathrm{ABB}}\right)$ can be calculated from the partial molar volumes of transfer $\left(\Delta_{\text {tr }} \phi_{V}\right)$ by using the following equation:

$$
\Delta_{\mathrm{tr}} \phi_{V}=2 V_{\mathrm{AB}} m_{\mathrm{c}}+3 V_{\mathrm{ABB}} m_{\mathrm{c}}^{2}+\cdots
$$

where A denotes glycine/L-alanine, B denotes CA and $m_{\mathrm{c}}$ is the molality of CA. The $V_{\mathrm{AB}}$ and $V_{\mathrm{ABB}}$ values of glycine/L-alanine in aqueous CA solutions are given in Table 4 . The $V_{\mathrm{AB}}$ values for glycine (except at $298.15 \mathrm{~K}$ ) and L-alanine in aqueous CA solutions are found to be negative at different temperatures. On the other hand, the $V_{\mathrm{ABB}}$ values are negative for glycine and positive for L-alanine over the entire temperature range. From Table 4 it is also observed that the magnitude of $V_{\mathrm{AB}}$ and $V_{\mathrm{ABB}}$ values for L-alanine are greater than for glycine in CA, which suggest that L-alanine interacts more strongly with CA. Overall, the higher magnitude of $V_{\mathrm{ABB}}$ values for L-alanine in CA at the studied temperatures indicates the dominance of triplet interactions. Pair interactions dominate for glycine in the presence of CA at lower temperatures (i.e. 288.15 and $298.15 \mathrm{~K}$ ) whereas at higher temperatures (i.e. 308.15, 310.15 and $318.15 \mathrm{~K}$ ) triplet interactions dominate. The reverse trend of $V_{\mathrm{AB}}$ and $V_{\mathrm{ABB}}$ values has been observed for glycine in SA, i.e. $V_{\mathrm{AB}}$ dominates at high temperature whereas $V_{\mathrm{ABB}}$ dominates at low temperature (no specific reason mentioned). The observed behavior of $V_{\mathrm{AB}}$ and $V_{\mathrm{ABB}}$ values for glycine in CA may be attributed to the presence of some cooperativity in the interaction of the alkyl group (hydrocarbon part), i.e. when two hydrocarbon groups come in contact with each other then it is easier for the third group to join the other two [45]. 
Table 3 Limiting partial molar volumes $\left(\phi_{V}^{\mathrm{o}}\right)$ of glycine/L-alanine in water and in aqueous CA solutions at $T=(288.15,298.15,308.15,310.15$ and 318.15$) \mathrm{K}$

\begin{tabular}{|c|c|c|c|c|c|}
\hline \multirow[t]{2}{*}{$m_{\mathrm{c}}\left(\mathrm{mol} \cdot \mathrm{kg}^{-1}\right)$} & \multicolumn{5}{|l|}{$10^{6} \times \phi_{V}^{\mathrm{o}}\left(\mathrm{m}^{3} \cdot \mathrm{mol}^{-1}\right)$} \\
\hline & $288.15, T(\mathrm{~K})$ & $298.15, T(\mathrm{~K})$ & $308.15, T(\mathrm{~K})$ & $310.15, T(\mathrm{~K})$ & $318.15, T(\mathrm{~K})$ \\
\hline \multicolumn{6}{|l|}{ Glycine } \\
\hline 0.00 & $\begin{array}{l}42.37^{\mathrm{a}} \pm 0.02 \\
(1.01)^{\mathrm{b}} \\
{[0.99]^{\mathrm{c}}} \\
42.69^{\mathrm{d}}, 42.37^{\mathrm{e}}, 42.38^{\mathrm{f}}\end{array}$ & $\begin{array}{l}43.16^{\mathrm{a}} \pm 0.03 \\
(0.93) \\
{[0.99]} \\
43.51^{\mathrm{d}}, 43.27^{\mathrm{e}}, \\
\quad 42.28^{\mathrm{f}} 43.16^{\mathrm{g}},\end{array}$ & $\begin{array}{l}43.86^{\mathrm{a}} \pm 0.02 \\
(0.66) \\
{[0.99]} \\
43.77^{\mathrm{d}}, 43.98^{\mathrm{e}}, \\
\quad 43.76^{\mathrm{f}} 43.87^{\mathrm{h}}\end{array}$ & $\begin{array}{l}43.87^{\mathrm{a}} \pm 0.03 \\
(0.76) \\
{[0.99]} \\
44.10^{\mathrm{d}}\end{array}$ & $\begin{array}{l}44.16^{\mathrm{a}} \pm 0.02 \\
(0.75) \\
{[0.99]} \\
44.43^{\mathrm{d}}, 44.16^{\mathrm{f}} \\
\quad 44.17^{\mathrm{i}}, \\
44.14^{\mathrm{j}}\end{array}$ \\
\hline 0.05 & $\begin{array}{l}42.32 \pm 0.01 \\
(0.92) \\
{[0.99]}\end{array}$ & $\begin{array}{l}43.14 \pm 0.02 \\
(0.92) \\
{[0.99]}\end{array}$ & $\begin{array}{l}43.61 \pm 0.03 \\
(0.96) \\
{[0.99]}\end{array}$ & $\begin{array}{l}43.80 \pm 0.02 \\
(0.81) \\
{[0.99]}\end{array}$ & $\begin{array}{l}44.10 \pm 0.02 \\
(0.82) \\
{[0.99]}\end{array}$ \\
\hline 0.10 & $\begin{array}{l}42.18 \pm 0.01 \\
(0.82) \\
{[0.99]}\end{array}$ & $\begin{array}{l}43.07 \pm 0.02 \\
(0.89) \\
{[0.99]}\end{array}$ & $\begin{array}{l}43.54 \pm 0.02 \\
(0.95) \\
{[0.98]}\end{array}$ & $\begin{array}{l}43.60 \pm 0.02 \\
(0.97) \\
{[0.99]}\end{array}$ & $\begin{array}{l}43.87 \pm 0.03 \\
(1.02) \\
{[0.99]}\end{array}$ \\
\hline 0.20 & $\begin{array}{l}42.08 \pm 0.03 \\
{[0.99]} \\
{[0.99]}\end{array}$ & $\begin{array}{l}42.69 \pm 0.05 \\
(1.34) \\
{[0.99]}\end{array}$ & $\begin{array}{l}43.16 \pm 0.04 \\
(1.39) \\
{[0.99]}\end{array}$ & $\begin{array}{l}43.20 \pm 0.05 \\
(1.44) \\
{[0.99]}\end{array}$ & $\begin{array}{l}43.35 \pm 0.07 \\
(1.59) \\
{[0.99]}\end{array}$ \\
\hline 0.30 & $\begin{array}{l}41.98 \pm 0.02 \\
(0.92) \\
{[0.99]}\end{array}$ & $\begin{array}{l}42.46 \pm 0.04 \\
(1.48) \\
{[0.99]}\end{array}$ & $\begin{array}{l}42.89 \pm 0.05 \\
(1.66) \\
{[0.99]}\end{array}$ & $\begin{array}{l}43.10 \pm 0.05 \\
(1.48) \\
{[0.99]}\end{array}$ & $\begin{array}{l}43.29 \pm 0.04 \\
(1.65) \\
{[0.99]}\end{array}$ \\
\hline 0.40 & $\begin{array}{l}41.43 \pm 0.03 \\
(1.35) \\
{[0.99]}\end{array}$ & $\begin{array}{l}41.82 \pm 0.02 \\
(1.04) \\
{[0.99]}\end{array}$ & $\begin{array}{l}42.31 \pm 0.01 \\
(0.54) \\
{[0.99]}\end{array}$ & $\begin{array}{l}42.66 \pm 0.02 \\
(0.77) \\
{[0.99]}\end{array}$ & $\begin{array}{l}42.97 \pm 0.03 \\
(0.74) \\
{[0.99]}\end{array}$ \\
\hline 0.50 & $\begin{array}{l}41.37 \pm 0.01 \\
(1.18) \\
{[0.99]}\end{array}$ & $\begin{array}{l}41.63 \pm 0.02 \\
(1.72) \\
{[0.99]}\end{array}$ & $\begin{array}{l}42.26 \pm 0.02 \\
(0.73) \\
{[0.99]}\end{array}$ & $\begin{array}{l}42.46 \pm 0.01 \\
(0.72) \\
{[0.99]}\end{array}$ & $\begin{array}{l}42.94 \pm 0.02 \\
(1.42) \\
{[0.99]}\end{array}$ \\
\hline \multicolumn{6}{|l|}{ L-Alanine } \\
\hline 0.00 & $\begin{array}{l}59.66^{\mathrm{a}} \pm 0.02 \\
(0.76) \\
{[0.99]} \\
59.67^{\mathrm{e}}\end{array}$ & $\begin{array}{l}60.35^{\mathrm{a}} \pm 0.02 \\
(0.64) \\
{[0.99]} \\
60.42^{\mathrm{e}}\end{array}$ & $\begin{array}{l}60.84^{\mathrm{a}} \pm 0.02 \\
(0.62) \\
{[0.99]} \\
60.88^{\mathrm{e}}\end{array}$ & $\begin{array}{l}60.94^{\mathrm{a}} \pm 0.02 \\
(0.59) \\
{[0.99]}\end{array}$ & $\begin{array}{l}61.15^{\mathrm{a}} \pm 0.03 \\
(0.74) \\
{[0.99]}\end{array}$ \\
\hline 0.05 & $\begin{array}{l}59.53 \pm 0.02 \\
(0.97) \\
{[0.99]}\end{array}$ & $\begin{array}{l}59.62 \pm 0.02 \\
(1.19) \\
{[0.99]}\end{array}$ & $\begin{array}{l}59.71 \pm 0.02 \\
(1.18) \\
{[0.99]}\end{array}$ & $\begin{array}{l}59.80 \pm 0.02 \\
(1.16) \\
{[0.99]}\end{array}$ & $\begin{array}{l}60.00 \pm 0.02 \\
(1.04) \\
{[0.99]}\end{array}$ \\
\hline 0.10 & $\begin{array}{l}59.44 \pm 0.01 \\
(0.96) \\
{[0.99]}\end{array}$ & $\begin{array}{l}59.51 \pm 0.02 \\
(0.98) \\
{[0.99]}\end{array}$ & $\begin{array}{l}59.62 \pm 0.03 \\
(1.01) \\
{[0.99]}\end{array}$ & $\begin{array}{l}59.72 \pm 0.02 \\
(0.96) \\
{[0.99]}\end{array}$ & $\begin{array}{l}59.85 \pm 0.03 \\
(1.09) \\
{[0.99]}\end{array}$ \\
\hline 0.20 & $\begin{array}{l}59.31 \pm 0.02 \\
(1.01) \\
{[0.99]}\end{array}$ & $\begin{array}{l}59.48 \pm 0.01 \\
(0.94) \\
{[0.99]}\end{array}$ & $\begin{array}{l}59.57 \pm 0.01 \\
(0.95) \\
{[0.99]}\end{array}$ & $\begin{array}{l}59.59 \pm 0.01 \\
(1.08) \\
{[0.99]}\end{array}$ & $\begin{array}{l}59.74 \pm 0.03 \\
(1.14) \\
{[0.99]}\end{array}$ \\
\hline 0.30 & $\begin{array}{l}59.21 \pm 0.01 \\
(0.90) \\
{[0.99]}\end{array}$ & $\begin{array}{l}59.31 \pm 0.02 \\
(1.02) \\
{[0.99]}\end{array}$ & $\begin{array}{l}59.42 \pm 0.02 \\
(0.95) \\
{[0.99]}\end{array}$ & $\begin{array}{l}59.52 \pm 0.03 \\
(0.97) \\
{[0.99]}\end{array}$ & $\begin{array}{l}59.61 \pm 0.03 \\
(1.05) \\
{[0.99]}\end{array}$ \\
\hline 0.40 & $\begin{array}{l}59.13 \pm 0.02 \\
(0.92) \\
{[0.99]}\end{array}$ & $\begin{array}{l}59.26 \pm 0.02 \\
(0.94) \\
{[0.99]}\end{array}$ & $\begin{array}{l}59.36 \pm 0.03 \\
(0.98) \\
{[0.99]}\end{array}$ & $\begin{array}{l}59.44 \pm 0.03 \\
(0.99) \\
{[0.99]}\end{array}$ & $\begin{array}{l}59.52 \pm 0.03 \\
(1.09) \\
{[0.99]}\end{array}$ \\
\hline 0.50 & $\begin{array}{l}59.05 \pm 0.01 \\
(1.00) \\
{[0.99]}\end{array}$ & $\begin{array}{l}59.12 \pm 0.02 \\
(1.08) \\
{[0.99]}\end{array}$ & $\begin{array}{l}59.28 \pm 0.02 \\
(0.95) \\
{[0.99]}\end{array}$ & $\begin{array}{l}59.32 \pm 0.03 \\
(1.02) \\
{[0.99]}\end{array}$ & $\begin{array}{l}59.44 \pm 0.03 \\
(1.00) \\
{[0.99]}\end{array}$ \\
\hline
\end{tabular}


Table 3 (continued)

\section{${ }^{\mathrm{a}}$ Present work}

${ }^{\mathrm{b}} S_{\mathrm{v}} \times 10^{6}\left(\mathrm{~m}^{3} \cdot \mathrm{kg} \cdot \mathrm{mol}^{-2}\right)$ values in parenthesis ()

${ }^{\mathrm{c}}$ Regression coefficient values in square brackets []

${ }^{\mathrm{d}}$ Reference [23]

e Reference [26]

${ }^{\mathrm{f}}$ Reference [8]

geference [27]

${ }^{\mathrm{h}}$ Reference [35]

${ }^{\mathrm{i}}$ Reference [36]

${ }^{\mathrm{j}}$ Reference [28]

The standard uncertainties in molality, $\mathrm{u}\left(m_{\mathrm{A}}\right)$ is $\leq 5.86 \times 10^{-3} \mathrm{~mol} \cdot \mathrm{kg}^{-1}$

The standard uncertainty in temperature, $\mathrm{u}(T)$ is $0.03 \mathrm{~K}$

The standard uncertainty in pressure, $\mathrm{u}(p)$ is $0.5 \mathrm{kPa}$

The standard uncertainty in partial molar volume, $u\left(\phi_{\mathrm{v}}^{\mathrm{o}}\right)$ is $\leq 0.07 \times 10^{-6} \mathrm{~m}^{3} \cdot \mathrm{mol}^{-1}$

\pm Respective errors in $\phi_{V}^{\circ}$ values

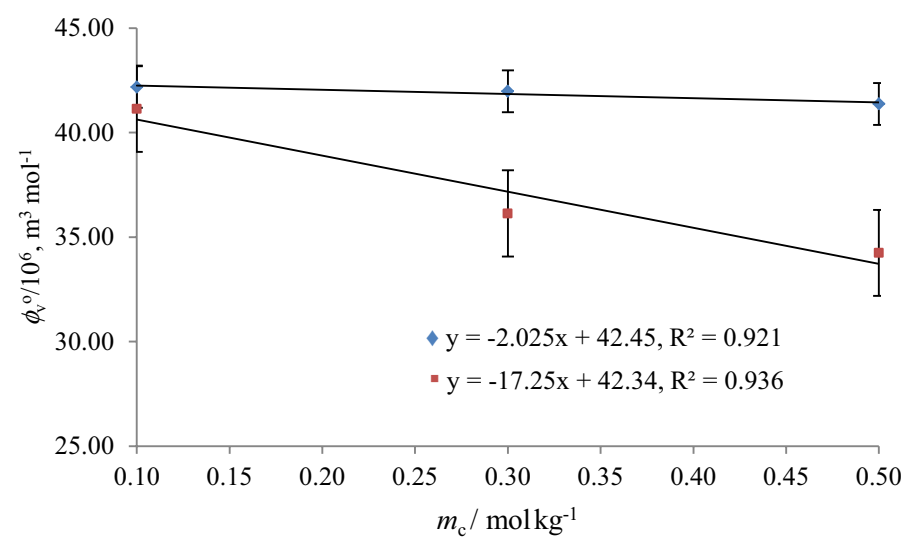

Fig. 8 Representative plots of limiting partial molar volumes $\phi_{V}^{o}$ versus molality $\left(m_{\mathrm{c}}\right)$ of glycine in: blue filled diamond, aqueous CA solutions and red filled square, in aqueous SA solutions at 288.15 K (Color figure online)

To study the effect of temperature on $\phi_{V}^{\mathrm{o}}$, the limiting partial molar expansibilities $\left(\partial \phi_{V}^{\mathrm{o}} / \partial T\right)_{p}$ and their second-order derivatives $\left(\partial^{2} \phi_{V}^{\mathrm{o}} / \partial T^{2}\right)_{p}$ have been calculated by fitting the following equation to the corresponding data:

$$
\phi_{V}^{\mathrm{o}}=a+b T+c T^{2}
$$

where $a, b$ and $c$ are constants and $T$ is the absolute temperature. The $\left(\partial \phi_{V}^{o} / \partial T\right)_{p}$ and $\left(\partial^{2} \phi_{V}^{\mathrm{o}} / \partial T^{2}\right)_{p}$ values of glycine/L-alanine in water are $\left(0.097 \mathrm{~m}^{3} \cdot \mathrm{mol}^{-1} \cdot \mathrm{K}^{-1}\right.$, $\left.-0.0023 \mathrm{~m}^{3} \cdot \mathrm{mol}^{-1} \cdot \mathrm{K}^{-2}\right)$ and $\left(0.079 \mathrm{~m}^{3} \cdot \mathrm{mol}^{-1} \cdot \mathrm{K}^{-1},-0.0019 \mathrm{~m}^{3} \cdot \mathrm{mol}^{-1} \cdot \mathrm{K}^{-2}\right)$, respectively, which agree well with the literature values $[27,28,34]$ and are summarized in Table 5 . The $\left(\partial^{2} \phi_{V}^{\mathrm{o}} / \partial T^{2}\right)_{p}$ values of glycine in aqueous CA solutions decrease with increasing temperature except at $m_{\mathrm{c}}=(0.4$ and 0.5$) \mathrm{mol} \cdot \mathrm{kg}^{-1}$ whereas the $\left(\partial^{2} \phi_{V}^{\mathrm{o}} / \partial T^{2}\right)_{p}$ values for L-alanine increase with increasing temperature. 


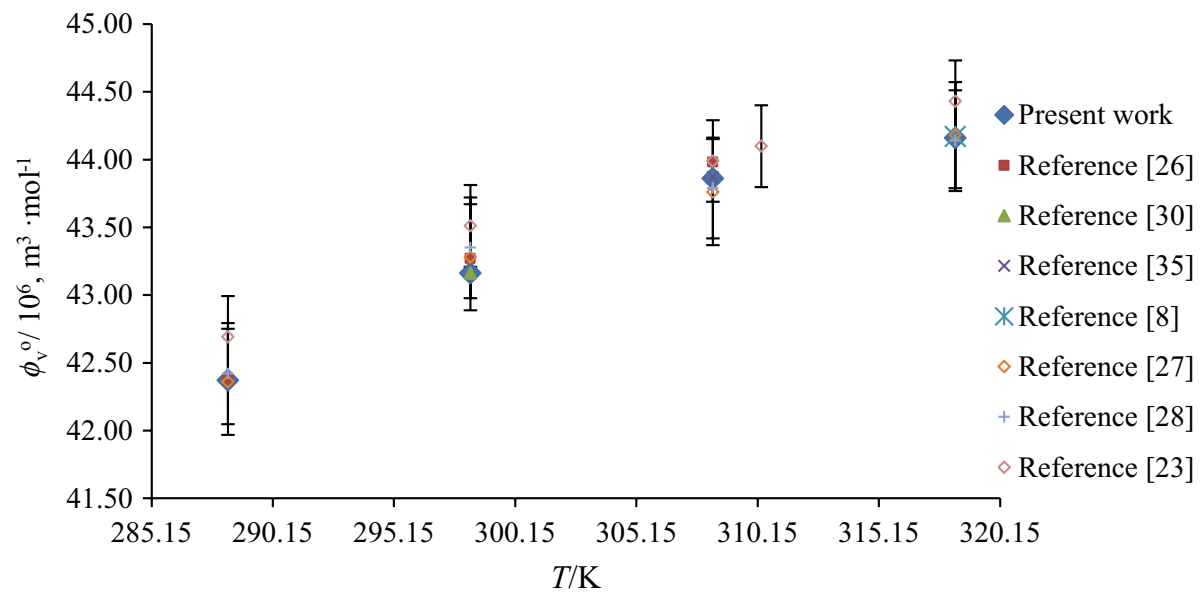

Fig. 9 Comparative plots of limiting partial molar volumes $\left(\phi_{V}^{\mathrm{o}}\right)$ of glycine in water versus temperature, $T=(288.15-318.15) \mathrm{K}$

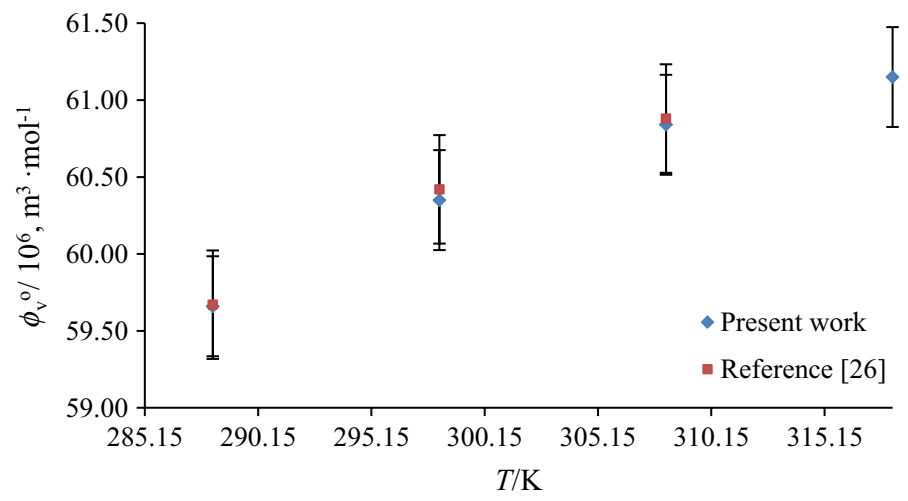

Fig. 10 Comparative plots of limiting partial molar volumes $\left(\phi_{V}^{\mathrm{o}}\right)$ of L-alanine in water versus temperature, $T=(288.15-318.15) \mathrm{K}$

Hepler [46] used the following thermodynamic relation by which qualitative information regarding hydration of a solute can be evaluated from the thermal expansion:

$$
\left(\partial C_{p}^{\mathrm{o}} / \partial p\right)_{T}=-T\left(\partial^{2} \phi_{V}^{\mathrm{o}} / \partial T^{2}\right)_{p}
$$

where $C_{p}^{\mathrm{o}}$ is the partial molar heat capacity. The sign of $\left(\partial C_{p}^{\mathrm{o}} / \partial p\right)_{T}$ and its temperature dependence should provide a distinction between the structure making or breaking ability of solutes in solution. According to Eq. 7, a structure-breaking solute should have negative $\left(\partial^{2} \phi_{V}^{\mathrm{o}} / \partial T^{2}\right)_{p}$ values whereas positive $\left(\partial^{2} \phi_{V}^{\mathrm{o}} / \partial T^{2}\right)_{p}$ values suggest that the solute behaves as a structure maker. It can be seen from Table 5 that glycine predominantly acts as a structure breaker whereas L-alanine acts as a structure maker. It is concluded that the 


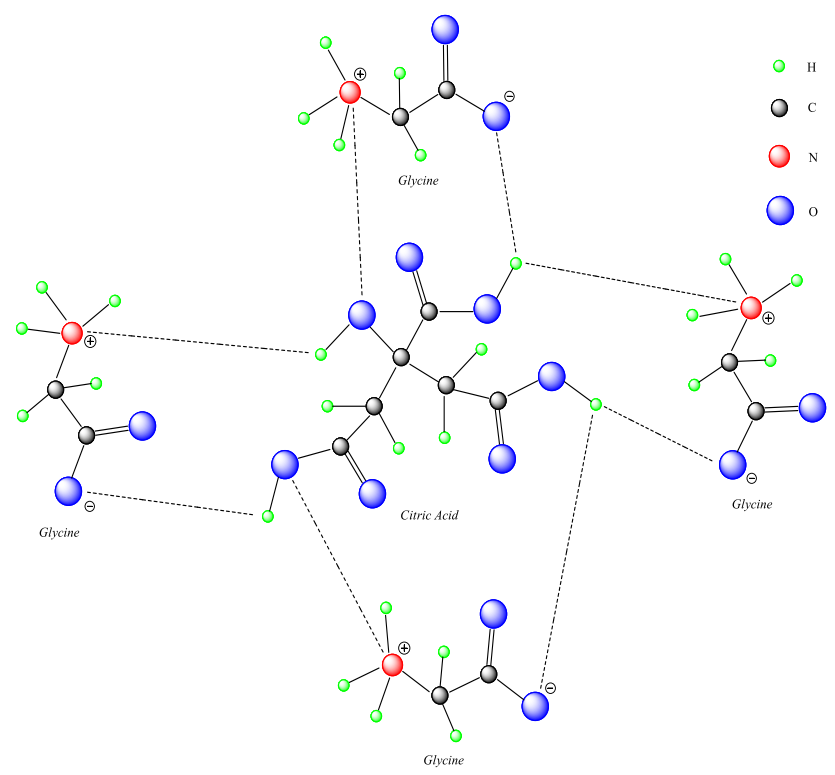

(i)

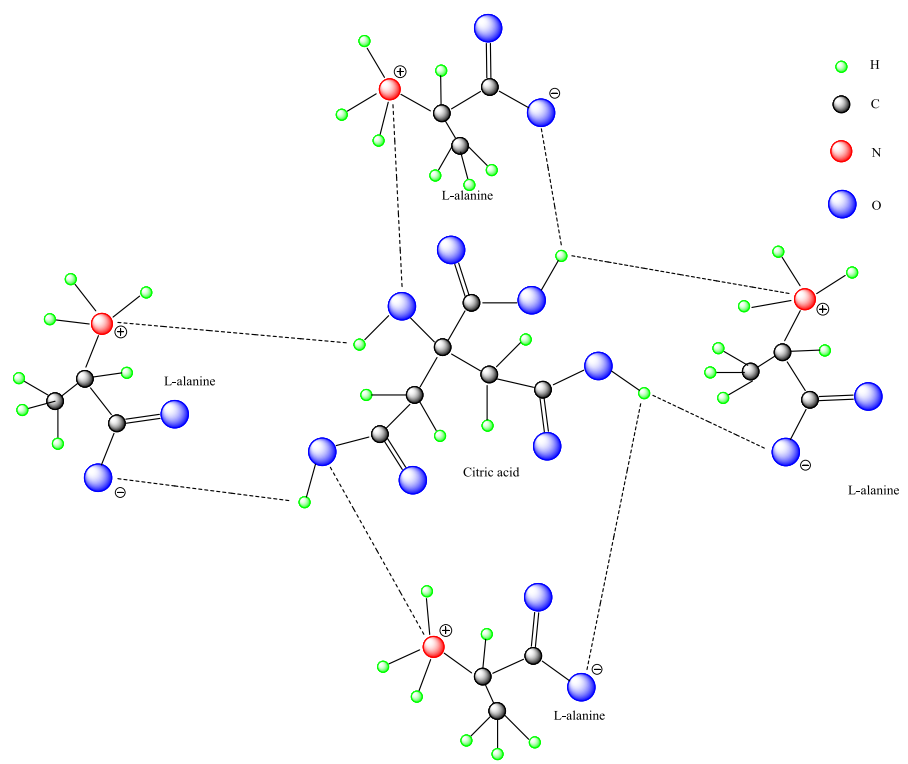

(ii)

Scheme 2 Different types of possible interactions (i) glycine-CA and (ii) L-alanine-CA at pH 2.12 and at $T=310.15 \mathrm{~K}$

structure-breaking and structure-making behavior of glycine and L-alanine in CA may be attributed to the absence of the caging effect [47]. Similar behavior for glycine in SA is observed for the $\left(\partial^{2} \phi_{V}^{\mathrm{o}} / \partial T^{2}\right)_{p}$ values. Overall, the structure breaking tendency of glycine 


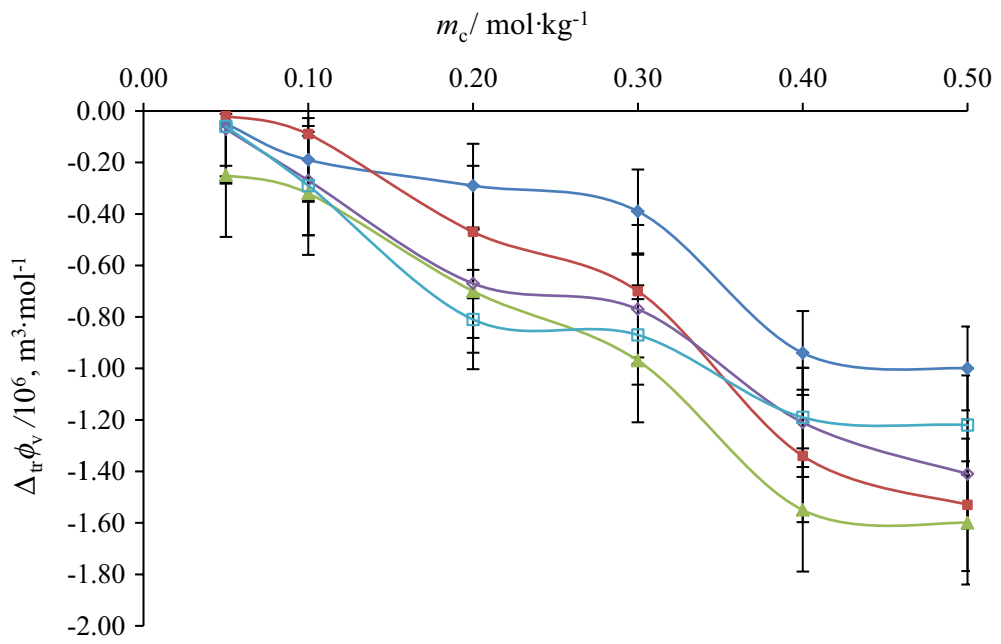

Fig. 11 Plots of partial molar volumes of transfer $\left(\Delta_{\mathrm{tr}} \phi_{V}\right)$ versus molalities $\left(m_{\mathrm{c}}\right)$ of CA of glycine at different temperatures: $T=$ blue filled diamond, 288.15, red filled square, 298.15; Green filled triangle, 308.15; Violet open diamond, 310.15; blue open square, 318.15 K (Color figure online)

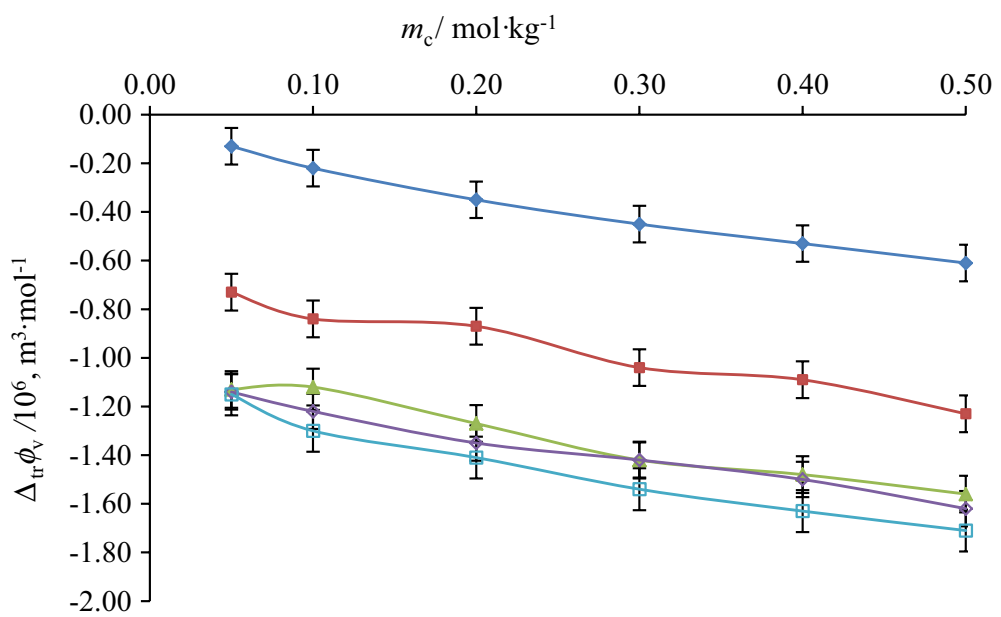

Fig. 12 Plots of partial molar volumes of transfer $\left(\Delta_{\mathrm{tr}} \phi_{V}\right)$ versus molalities $\left(m_{c}\right)$ of CA of L-alanine at different temperatures: $T=$ blue filled diamond, 288.15; red filled square, 298.15; Green filled triangle, 308.15; Violet open diamond, 310.15; blue open square, 318.15 K (Color figure online)

in the presence of CA is higher than for glycine in SA [23]. This may be attributed due to partial dissociation of CA which tends to destruct the hydrogen bonded structure of water, and then water behaves as a normal (i.e. non associated) liquid. The equilibrium of different water species (i.e., a hydrogen bonded structure associated with a normal liquid) is temperature dependent. Elevation in temperature leads to the expansion of volume with increase in the fraction of non-associated water molecules. In addition, the water structure 
Table 4 Pair $\left(V_{\mathrm{AB}}\right)$ and triplet $\left(V_{\mathrm{ABB}}\right)$ interaction coefficients of glycine/L-alanine in aqueous CA solutions at $T=(288.15$ to 318.15) K

\begin{tabular}{lll}
\hline$T(\mathrm{~K})$ & $10^{6} \times V_{\mathrm{AB}}\left(\mathrm{m}^{3} \cdot \mathrm{mol}^{-2} \cdot \mathrm{kg}\right)$ & $10^{6} \times V_{\mathrm{ABB}}\left(\mathrm{m}^{3} \cdot \mathrm{mol}^{-3} \cdot \mathrm{kg}^{2}\right)$ \\
\hline Glycine & & \\
288.15 & $-0.33(-12.28)_{\mathrm{SA}}$ & $-1.62(12.69)_{\mathrm{SA}}$ \\
298.15 & $0.19(-11.68)_{\mathrm{SA}}$ & $-5.07(3.82)_{\mathrm{SA}}$ \\
308.15 & $-1.40(0.64)_{\mathrm{SA}}$ & $-1.69(-33.95)_{\mathrm{SA}}$ \\
310.15 & $-1.40(0.91)_{\mathrm{SA}}$ & $-0.22(-35.34)_{\mathrm{SA}}$ \\
318.15 & $-1.64(1.22)_{\mathrm{SA}}$ & $-0.59(-39.19)_{\mathrm{SA}}$ \\
L-Alanine & & \\
288.15 & -1.32 & 1.75 \\
298.15 & -5.82 & 13.51 \\
308.15 & -8.35 & 19.42 \\
310.15 & -8.99 & 21.48 \\
318.15 & -9.25 & 21.58 \\
\hline
\end{tabular}

()$_{\mathrm{SA}}$ are the $V_{\mathrm{AB}}$ and $V_{\mathrm{ABB}}$ values of glycine in aqueous $\mathrm{SA}$ solutions [23]

changes from the combined effects of increased temperature and with increase in the CA concentration [19].

\subsection{Hydration Number}

The hydration number $\left(n_{\mathrm{H}}\right)$ reflects the electrostriction effect of the charge centers of amino acids on nearby water molecules. Millero et al. [48] reported a relationship between the limiting electrostriction contribution to the partial molar volume and hydration number of the non-electrolytes as:

$$
\phi_{V, \text { elect }}=n_{\mathrm{H}}\left(\phi_{V, \mathrm{e}}^{\mathrm{o}}-\phi_{V, \mathrm{~b}}^{\mathrm{o}}\right)
$$

where $\phi_{V, \mathrm{e}}^{\mathrm{o}}$ is the limiting molar volume of electrostricted water and $\phi_{V, \mathrm{~b}}^{\mathrm{o}}$ is the molar volume of bulk water. For every water molecule taken from the bulk phase to the region near an AA, the $\left(\phi_{V, \mathrm{e}}^{\mathrm{o}}-\phi_{V, \mathrm{~b}}^{\mathrm{o}}\right)$ values are $-2.9,-3.3$ and -4.0$) \times 10^{-2} \mathrm{~m}^{3} \cdot \mathrm{mol}^{-1}$ at $T=(288.15$, 298.15 and 308.15) K, respectively [48]. The $n_{\mathrm{H}}$ values of glycine/L-alanine in water and in aqueous CA solutions are summarized in Table 6 . The $n_{\mathrm{H}}$ values of glycine/L-alanine in water are in good agreement with the literature values and are shown in Figs. 13 and 14 [26-28, 49]. The $n_{\mathrm{H}}$ values of glycine and L-alanine increase with increase in the concentration of CA, which further suggests that water in the immediate vicinity of charged centers of glycine/L-alanine in aqueous CA solutions is highly electrostricted leading to higher $n_{\mathrm{H}}$ values. The decrease in $n_{\mathrm{H}}$ values with increases in temperature may be attributed to the weakening of the electrostriction effect of charged centers, which then leads to stronger interactions between glycine-CA and L-alanine-CA. It also shows that CA exerts a dehydration effect in the present systems.

Lower $n_{\mathrm{H}}$ values for glycine/L-alanine in water than in CA indicate that glycine/L-alanine are more hydrated in the presence of CA. Also, the higher $n_{\mathrm{H}}$ values for glycine in SA than in CA further suggests that SA has a strong dehydrating effect on glycine. This may be due to the presence of hydrophilic groups (i.e., $-\mathrm{OH}$ and $-\mathrm{COOH}$ in $\mathrm{CA}$ ) which leads to the formation of hydrogen bonding. 
Table 5 Limiting partial molar expansibilities $\left(\partial \phi_{V}^{\mathrm{o}} / \partial T\right)_{p}$ and their second-order derivatives $\left(\partial^{2} \phi_{V}^{\mathrm{o}} / \partial T^{2}\right)_{p}$ for glycine/L-alanine in water and in aqueous CA solutions at $T=(288.15$ to 318.15$) \mathrm{K}$

\begin{tabular}{|c|c|c|c|c|c|c|}
\hline \multirow[t]{2}{*}{$m_{\mathrm{c}}\left(\mathrm{mol} \cdot \mathrm{kg}^{-1}\right)$} & \multicolumn{5}{|c|}{$\left(\partial \phi_{V}^{\mathrm{o}} / \partial T\right)_{p}\left(\mathrm{~m}^{3} \cdot \mathrm{mol}^{-1} \cdot \mathrm{K}^{-1}\right)$} & \multirow{2}{*}{$\begin{array}{l}\left(\partial^{2} \phi_{V}^{\mathrm{o}} / \partial T^{2}\right)_{p} \\
\left(\mathrm{~m}^{3} \cdot \mathrm{mol}^{-1} \cdot \mathrm{K}^{-2}\right)\end{array}$} \\
\hline & $T(\mathrm{~K}): 288.15$ & 298.15 & 308.15 & 310.15 & 318.15 & \\
\hline \multicolumn{7}{|l|}{ Glycine } \\
\hline 0.00 & $\begin{array}{l}0.096^{\mathrm{a}} \\
(0.097)^{\mathrm{b}}\end{array}$ & $\begin{array}{l}0.072^{\mathrm{a}} \\
(0.072)^{\mathrm{b}} \\
(0.071)^{\mathrm{c}}\end{array}$ & $\begin{array}{l}0.049^{\mathrm{a}} \\
(0.047)^{\mathrm{b}}\end{array}$ & $0.044^{\mathrm{a}}$ & $\begin{array}{l}0.025^{\mathrm{a}} \\
(0.022)^{\mathrm{b}}\end{array}$ & $\begin{array}{l}-0.0024^{\mathrm{a}} \\
(-0.0025)^{\mathrm{b}}\end{array}$ \\
\hline 0.05 & 0.084 & 0.067 & 0.049 & 0.046 & 0.032 & -0.0018 \\
\hline 0.10 & $\begin{array}{l}0.097 \\
(0.125)_{\mathrm{SA}}\end{array}$ & $\begin{array}{l}0.071 \\
(0.093)_{\mathrm{SA}}\end{array}$ & $\begin{array}{l}0.044 \\
(0.061)_{\mathrm{SA}}\end{array}$ & $\begin{array}{l}0.039 \\
(0.054)_{\mathrm{SA}}\end{array}$ & $\begin{array}{l}0.018 \\
(0.029)_{\mathrm{SA}}\end{array}$ & $\begin{array}{l}-0.0026 \\
(-0.0032)_{\mathrm{SA}}\end{array}$ \\
\hline 0.20 & 0.075 & 0.054 & 0.033 & 0.029 & 0.012 & -0.0021 \\
\hline 0.30 & $\begin{array}{l}0.056 \\
(0.486)_{\mathrm{SA}}\end{array}$ & $\begin{array}{l}0.048 \\
(0.416)_{\mathrm{SA}}\end{array}$ & $\begin{array}{l}0.041 \\
(0.346)_{\mathrm{SA}}\end{array}$ & $\begin{array}{l}0.040 \\
(0.332)_{\mathrm{SA}}\end{array}$ & $\begin{array}{l}0.034 \\
(0.276)_{\mathrm{SA}}\end{array}$ & $\begin{array}{l}-0.0007 \\
(-0.0074)_{\mathrm{SA}}\end{array}$ \\
\hline 0.40 & 0.041 & 0.049 & 0.057 & 0.058 & 0.065 & 0.0008 \\
\hline 0.50 & $\begin{array}{l}0.027 \\
(-0.219)_{\mathrm{SA}}\end{array}$ & $\begin{array}{l}0.045 \\
(-0.149)_{\mathrm{SA}}\end{array}$ & $\begin{array}{l}0.063 \\
(-0.079)_{\mathrm{SA}}\end{array}$ & $\begin{array}{l}0.067 \\
(-0.065)_{\mathrm{SA}}\end{array}$ & $\begin{array}{l}0.081 \\
(-0.009)_{\mathrm{SA}}\end{array}$ & $\begin{array}{l}0.0018 \\
(0.0075)_{\mathrm{SA}}\end{array}$ \\
\hline \multicolumn{7}{|l|}{ L-Alanine } \\
\hline 0.00 & 0.079 & $\begin{array}{l}0.060 \\
(0.062)^{\mathrm{d}}\end{array}$ & 0.040 & 0.036 & 0.021 & -0.0019 \\
\hline 0.05 & 0.008 & 0.010 & 0.020 & 0.022 & 0.029 & -0.0010 \\
\hline 0.10 & 0.004 & 0.010 & 0.017 & 0.018 & 0.024 & 0.0007 \\
\hline 0.20 & 0.012 & 0.013 & 0.014 & 0.014 & 0.015 & 0.0001 \\
\hline 0.30 & 0.009 & 0.012 & 0.015 & 0.016 & 0.018 & 0.0003 \\
\hline 0.40 & 0.010 & 0.013 & 0.015 & 0.015 & 0.017 & 0.0002 \\
\hline 0.50 & 0.007 & 0.011 & 0.015 & 0.016 & 0.019 & 0.0004 \\
\hline
\end{tabular}

()$_{\mathrm{SA}}$ are the $\left(\partial \phi_{V}^{\circ} / \partial T\right)_{p}$ and $\left(\partial^{2} \phi_{V}^{\mathrm{o}} / \partial T^{2}\right)_{p}$ values of glycine in aqueous SA solutions [23]

${ }^{\text {a }}$ Present work

${ }^{\mathrm{b}}$ Reference [27]

${ }^{\mathrm{c}}$ Reference [28]

${ }^{\mathrm{d}}$ Reference [34]

\subsection{Apparent Specific Volumes and Taste Quality}

$\mathrm{CA}$ and inorganic citrates are active ingredients in many dosage forms. It is a natural preservative which is used to add an acidic or sour taste to foods and drinks. The taste behavior can be verified on the basis of the apparent specific volumes $\left(v_{\phi}\right)$ which gives a direct measure of the dislocation of water molecule by the solute and reflects its compatibility with water. $v_{\phi}$ has been calculated by using the following equation [50]:

$$
v_{\phi}=\phi_{v} / M
$$

where $\phi_{V}$ is the apparent molar volume and $M$ is the molar mass of glycine/L-alanine and $v_{\phi} \times 10^{-3} \mathrm{~m}^{3} \cdot \mathrm{kg}^{-1}$ bears a relationship to taste quality in the order salt $<\sim 0.33$, sour $\sim 0.33$ to $\sim 0.52$, sweet $\sim 0.52$ to $\sim 0.71$, and bitter $\sim 0.71$ to $\sim 0.93$ [51]. The $v_{\phi}$ values for CA in water, glycine/L-alanine in water, in aqueous $\mathrm{CA}$ and glycine in aqueous SA solutions are 
Table 6 Hydration number $\left(n_{\mathrm{H}}\right)$ of glycine/L-alanine in water and in aqueous CA solutions at $T=(288.15$, 298.15 and 308.15$) \mathrm{K}$

\begin{tabular}{clll}
\hline$m_{\mathrm{c}}\left(\mathrm{mol} \cdot \mathrm{kg}^{-1}\right)$ & $n_{\mathrm{H}}$ & & \\
\cline { 2 - 4 } & $T(\mathrm{~K}): 288.15$ & 298.15 & 308.15 \\
\hline Glycine & & & \\
0.00 & $3.27^{\mathrm{a}}$ & $2.64^{\mathrm{a}}$ & $2.00^{\mathrm{a} a}$ \\
& $\left(3.26^{\mathrm{b}}, 3.27^{\mathrm{c}}, 3.28^{\mathrm{d}}\right)$ & $\left(2.58^{\mathrm{b}}, 2.60^{\mathrm{c}}, 2.61^{\mathrm{d}}\right)$ & $\left(2.02^{\mathrm{b}, \mathrm{c}}, 1.97^{\mathrm{d}}\right)$ \\
0.05 & 3.29 & 2.64 & 2.06 \\
0.10 & $3.34(3.97)_{\mathrm{SA}}$ & $2.66(3.20)_{\mathrm{SA}}$ & $2.08(2.55)_{\mathrm{SA}}$ \\
0.20 & 3.37 & 2.78 & 2.18 \\
0.30 & $3.41(5.83)_{\mathrm{SA}}$ & $2.85(4.37)_{\mathrm{SA}}$ & $2.24(2.38)_{\mathrm{SA}}$ \\
0.40 & 3.60 & 3.04 & 2.39 \\
0.50 & $3.62(6.53)_{\mathrm{SA}}$ & $3.10(5.27)_{\mathrm{SA}}$ & $2.40(4.32)_{\mathrm{SA}}$ \\
$\mathrm{L}-\mathrm{Alanine}$ & & & \\
0.00 & $4.17^{\mathrm{a}}$ & $3.45^{\mathrm{a}}$ & $2.73^{\mathrm{a}}$ \\
& $\left(4.17^{\mathrm{d}}\right)$ & $\left(3.45^{\mathrm{b}}\right)$ & $\left(2.68^{\mathrm{b}}, 2.72^{\mathrm{d}}\right)$ \\
0.05 & 4.21 & 3.68 & 3.01 \\
0.10 & 4.24 & 3.71 & 3.03 \\
0.20 & 4.29 & 3.72 & 3.05 \\
0.30 & 4.32 & 3.77 & 3.08 \\
0.40 & 4.35 & 3.78 & 3.10 \\
0.50 & 4.38 & 3.83 & 3.12 \\
\hline
\end{tabular}

() $)_{\mathrm{SA}}$ are the $n_{\mathrm{H}}$ values of glycine in aqueous SA solutions [23]

${ }^{\text {a Present work }}$

${ }^{\mathrm{b}}$ Reference [28]

${ }^{\mathrm{c}}$ Reference [27]

${ }^{\mathrm{d}}$ Reference [49]

Fig. 13 Comparison plots of hydration number $\left(n_{\mathrm{H}}\right)$ of glycine in water at different temperatures, $T=(288.15,298.15$ and 308.15) $\mathrm{K}$

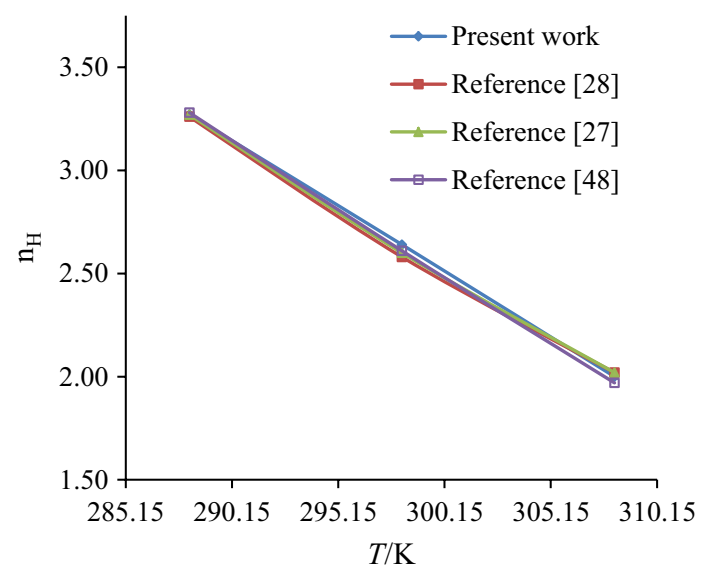


Fig. 14 Comparison plots of hydration number $\left(n_{\mathrm{H}}\right)$ of L-alanine in water at different temperatures, $T=(288.15,298.15$ and 308.15$) \mathrm{K}$

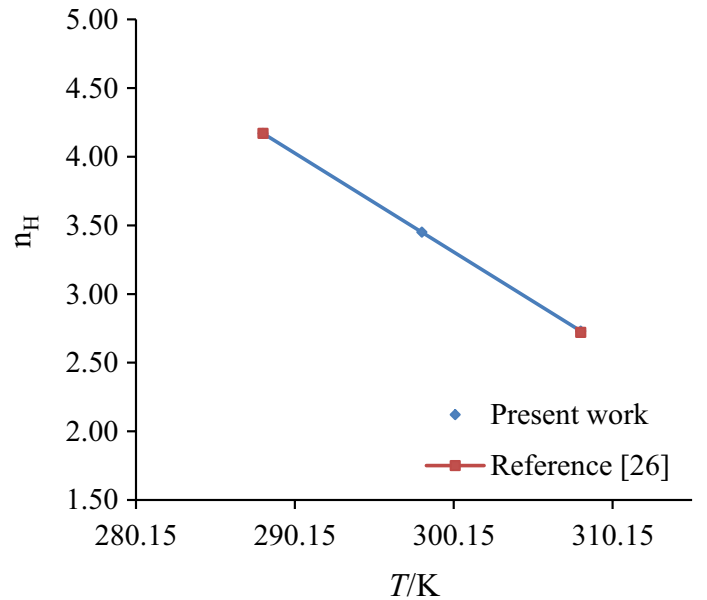

given in Table S2. It is observed from Table S2 that the $v_{\phi}$ values of glycine/L-alanine in water and in aqueous CA solutions (range from 0.55 to 0.69 ) fall in the sweet taste behavior range (except for L-alanine at $m_{\mathrm{c}}=0.05 \mathrm{~mol} \cdot \mathrm{kg}^{-1}$ ), which may be due to hydrophobic interactions occurring in these ternary systems. The result obtained from the $v_{\phi}$ values also supports $\Delta_{\text {tr }} \phi_{V}$ data, which further strengthens the view that hydrophobic interactions are dominating in these systems. In the case of SA, the $v_{\phi}$ values of glycine tend to show sourto-sweet taste behavior (ranges from 0.47 to 0.61 ) with increase in concentration and temperature. The obtained trend in SA may due to the displacement of a large number of water molecules by hydrophobic groups [52].

\section{Conclusions}

The negative $\Delta_{\mathrm{tr}} \phi_{V}$ values obtained for glycine/L-alanine in aqueous CA solutions suggest the dominance of hydrophilic-hydrophobic and hydrophobic-hydrophobic interactions in these systems. Triplet interactions dominate over pair interactions in the case of L-alanine compared to glycine in CA, which indicates that L-alanine interacts more strongly with CA. At low concentrations of CA, glycine/L-alanine act as structure breakers whereas at high concentrations of CA, glycine/L-alanine act as structure makers. Also, it is evident that CA has a dehydration effect on amino acids. The results obtained for $v_{\phi}$ values suggest that CA enhances the sweet taste behavior of glycine/L-alanine with rise in temperatures. Comparative studies of glycine in aqueous CA and aqueous SA solutions show that the stronger interactions exist between glycine-CA than for glycine-SA, which is attributed due to the presence of additional hydrophilic groups in CA that leads to the formation of hydrogen bonds.

Open Access This article is distributed under the terms of the Creative Commons Attribution 4.0 International License (http://creativecommons.org/licenses/by/4.0/), which permits unrestricted use, distribution, and reproduction in any medium, provided you give appropriate credit to the original author(s) and the source, provide a link to the Creative Commons license, and indicate if changes were made. 


\section{References}

1. Wu, G.: Amino acids: metabolism, functions and nutrition. Amino Acids 37, 1-17 (2009)

2. Chalikian, T.V., Breslauer, K.: Thermodynamic analysis of biomolecules: a volumetric approach. Curr. Opin. Struct. Biol. 8, 657-664 (1998)

3. Zhang, J., Zhu, C., Ma, Y.: Volumetric and viscometric properties of amino acids in aqueous maltitol solutions at $T=(293.15-323.15)$ K. J. Chem. Thermodyn. 111, 52-64 (2017)

4. Thoppil, A.A., Judy, E., Kishore, N.: Mode of action of betadine on some amino acids and globular proteins: thermodynamic considerations. J. Chem. Thermodyn. 111, 115-128 (2017)

5. Zhao, H.: Viscosity $B$-coefficients and standard partial molar volumes of amino acids, and their roles in interpreting the protein (enzyme) stabilization. J. Biophys. Chem. 122, 157-183 (2006)

6. Dhondge, S.S., Paliwal, R.L., Bhave, N.S., Pandhurnekar, C.P.: Study of thermodynamic properties of aqueous binary mixtures of glycine, L-alanine and $\beta$-alanine at low temperatures $(T=275.15$, 279.15 and 283.15) K. J. Chem. Thermodyn. 45, 114-120 (2012)

7. Yan, Z., Wang, J., Lu, J.: Apparent molar volumes and viscosities of some $\alpha$;-amino acids in aqueous sodium butyrate solutions at 298.15 K. J. Chem. Eng. Data 46, 217-222 (2001)

8. Banipal, T.S., Kahlon, G.K., Kaur, J., Singh, K., Mehra, V., Chawla, R., Banipal, P.K.: Volumetric properties of some $\alpha, \omega$-aminocarboxylic acids in aqueous sodium acetate and magnesium acetate solutions at $T=(288.15$ to 318.15) K. J. Chem. Eng. Data 55, 4864-4871 (2010)

9. Velez, J.S.L., Azzoni, A.R., Filcho, P.A.P.: Precipitation of lysozyme with sodium succinate, sodium tartrate and sodium citrate: solubility and osmotic second virial coefficient data. J. Chem. Thermodyn. 110, 25-32 (2017)

10. Chauhan, S., Pathania, L., Sharma, K., Kumar, G.: Volumetric, acoustical and viscometric behavior of glycine and DL-alanine in aqueous furosemide solutions at different temperatures. J. Mol. Liq. 212, 656-664 (2015)

11. Rodriguez, D.M., Romero, C.M.: Effect of temperature on the partial molar volumes and the partial molar compressibilities of $\alpha$-amino acids in water and in aqueous solutions of strong electrolytes. J. Mol. Liq. 233, 487-498 (2017)

12. Roy, S., Mahali, K., Dolui, B.K.: Thermodynamic solvation of a series of homologous $\alpha$-amino acids in aqueous mixtures of 1,2-dimethoxyethane. J. Solution Chem. 42, 1472-1487 (2013)

13. Liu, J.L., Hakin, A.W., Hedwig, G.R.: Volumetric properties of tri-peptides with non-polar sidechains: partial molar volumes at $T=(288.15$ to 313.15$) \mathrm{K}$ and partial molar expansions at $T=298.15 \mathrm{~K}$ of some peptides of sequence Gly-X-Gly in aqueous solution. J. Chem. Thermodyn. 41, 1232-1238 (2009)

14. Liu, J.L., Hakin, A.W., Hedwig, G.R.: Partial molar volumes and heat capacities of the N-acetyl amide derivatives of the amino acids asparagine, glutamine, tyrosine, and lysine monohydrochloride in aqueous solution at temperatures from $T=(288.15-328.15)$ K. J. Chem. Thermodyn. 38, 1640-1650 (2006)

15. Riyazuddeen, Khan, I.: Effect of temperature on volumetric and isentropic compressibility of glycine in aqueous $\mathrm{KCl} / \mathrm{NaCl}$ solutions. J. Mol. Liq. 152, 57-62 (2010)

16. Talele, P., Kishore, N.: Thermodynamics of the interactions of some amino acids and peptides with dodecyltrimethylammonium bromide and tetradecyltrimethylammonium bromide. J. Chem. Thermodyn. 70, 182-189 (2014)

17. Lomesh, S.K., Kumar, D.: Volumetric, viscosity and ultrasonic studies of solute-solute and solute-solvent interactions of glycine and diglycine in water and in aqueous citric acid at different temperatures. J. Mol. Liq. 241, 764-771 (2017)

18. Kumar, D., Lomesh, S.K., Nathan, V.: Molecular interaction studies of L-alanine and L-phenylalanine in water and in aqueous citric acid at different temperatures using volumetric, viscosity and ultrasonic methods. J. Mol. Liq. 247, 75-83 (2017)

19. Apelblat, A.: Citric Acid. Springer, New York (2014)

20. Zarska, M., Dzida, M., Aplelblat, A.: Surface tensions and densities of concentrated aqueous solutions of citric acid. J. Mol. Liq. 228, 91-95 (2017)

21. Lehninger, A.L., Nelson, D.L., Cox, M.M.: Principles of Biochemistry, 4th edn, pp. 435-461. WH Freeman, New York (2004)

22. Betta, P.D., Schulte, M.: Calculation of the aqueous thermodynamic properties of citric acid cycle intermediates and precursors and the estimation of high temperature and pressure equation of state parameters. Int. J. Mol. Sci. 10, 2809-2837 (2009)

23. Singh, G.S., Patyar, P., Kaur, T., Kaur, G.: Volumetric behavior of glycine in aqueous succinic acid and sodium succinate buffer at different temperatures. J. Mol. Liq. 222, 804-817 (2016)

24. Millero, F.J.: The apparent and partial molal volume of aqueous sodium chloride solutions at various temperatures. J. Phys. Chem. 74, 356-362 (1970) 
25. Zeimer, S.P., Niederhauser, T.L., Merkley, E.D., Price, J.L., Sorenson, E.C., McRae, B.R., Patterson, B.A., Origlia-Luster, M.L., Woolley, E.M.: Thermodynamics of proton dissociation from aqueous glycine at temperatures from 278.15 to $393.15 \mathrm{~K}$, molalities from 0.1 to $1.0 \mathrm{~mol} \cdot \mathrm{kg}^{-1}$, at the pressure 0.35 MPa: apparent molar heat capacities and apparent molar volumes of glycine, glycinium chloride, and sodium glycinate. J. Chem. Thermodyn. 38, 467-483 (2006)

26. Lark, B.S., Patyar, P., Banipal, T.S., Kishore, N.: Densities, partial molar volumes and heat capacities of glycine, L-alanine and L-leucine in aqueous magnesium chloride solutions at different temperatures. J. Chem. Eng. Data 49, 553-565 (2004)

27. Singh, V., Chattaroy, P.K., Banipal, P.K., Banipal, T.S., Gardas, R.L.: volumetric properties of amino acids in aqueous solutions of ammonium based protic ionic liquids. Fluid Phase Equilb. 85, 258-274 (2015)

28. Banipal, T.S., Kaur, J., Banipal, P.K., Singh, K.: Study of interactions between amino acids and zinc chloride in aqueous solutions through volumetric measurements at $T=(288.15$ to 318.15$) \mathrm{K}$. J. Chem. Eng. Data 53, 1803-1816 (2008)

29. Li, S., Sang, W., Lin, R.: Partial molar volumes of glycine, L-alanine, and L-serine in aqueous glucose solutions at $T=298.15$ K. J. Chem. Thermodyn. 34, 1761-1768 (2002)

30. Banipal, T.S., Kaur, D., Banipal, P.K.: Apparent molar volumes and viscosities of some amino acids in aqueous sodium acetate solutions at 298.15 K. J. Chem. Eng. Data 49, 1236-1246 (2004)

31. Yan, Z., Wang, J., Liu, W., Lu, J.: Apparent molar volumes and viscosity $B$-coefficients of some $\alpha$;-amino acids in aqueous solutions from 278.15 to $308.15 \mathrm{~K}$. Thermochim. Acta 334, 17-27 (1999)

32. Pal, A., Kumar, H., Maan, R., Sharma, H.K.: Solute-solvent interactions of glycine, L-alanine, and L-valine in aqueous 1-methyl-3-octylimidazolium chloride ionic liquid solutions in the temperature interval (288.15-308.15) K. Thermochim. Acta 590, 127-137 (2014)

33. Ziemer, S.P., Niederhauser, T.L., Price, J.L., Woolley, E.M., Sorenson J.L.: Thermodynamics of proton dissociations from aqueous alanine at temperatures from (278.15 to 393.15$) \mathrm{K}$, molalities from (0.0075 to 1.0$) \mathrm{mol} \cdot \mathrm{kg}^{-1}$, and at the pressure $0.35 \mathrm{MPa}$ : apparent molar heat capacities and apparent molar volumes of alanine, alaninium chloride, and sodium alaninate. J. Chem. Thermody. 38(8), 939-951 (2006)

34. Patterson, B.A., Woolley, E.M.: Thermodynamics of proton dissociations from aqueous citric acid: apparent molar volumes and apparent molar heat capacities of citric acid and its sodium salts at the pressure $0.35 \mathrm{MPa}$ and at temperatures from $278.15 \mathrm{~K}$ to $393.15 \mathrm{~K}$. J. Chem. Thermodyn. 33, 1735-1764 (2001)

35. Gopal, R., Aggarwal, D.K., Kumar, R.: Variation of limiting apparent molal volume with temperature in some amino acids in aqueous solutions. Indian J. Chem. 11, 1061-1062 (1973)

36. Banipal, T.S., Kapoor, P.: Partial molal volumes and expansibilities of some amino acids in aqueous solutions. J. Indian Chem. Soc. 76, 17-21 (1999)

37. Wang, X., Fu, R., Guo, Y., Lin, R.: Volumetric properties of amino acids in aqueous D-mannitol solutions at 298.15 K. J. Mol. Liq. 197, 73-76 (2014)

38. Kirkwood, J.G.: Theoretical studies upon dipolar ions. Chem. Rev. 24(2), 233-251 (1939)

39. Nain, A.K., Pal, R.: Neetu: volumetric, ultrasonic and viscometric studies on solute-solute and solute-solvent interactions of L-threonine in aqueous sucrose solutions at different temperatures. J. Chem. Thermodyn. 64, 172-181 (2013)

40. Dai, Y., Spronsen, J.V., Witkamp, G.J., Verpoorte, R., Choi, Y.H.: Natural deep eutectic solvents as new potential media for green technology. Anal. Chim. Acta 766, 61-68 (2013)

41. Gurney, R.W.: Ionic Processes in Solution, 15th edn. McGraw Hill, New York (1953)

42. Shahidi, F., Farrell, P.G., Edwards, J.T.: Partial molar volumes of organic compounds in water. III. Carbohydrates. J. Solution Chem. 5, 807-816 (1976)

43. McMillan Jr., W.G., Mayer, J.E.: The statistical thermodynamics of multicomponent systems. J. Chem. Phys. 13, 276-305 (1945)

44. Kozak, J.J., Knight, W., Kauzmann, W.: Solute-solute interactions in aqueous solutions. J. Chem. Phys. 68, 675-696 (1968)

45. Savage, J.J., Wood, R.H.: Enthalpy of dilution of aqueous mixtures of amides, sugars, urea, ethylene glycol, and pentaerythritol at $\mathbf{2 9 8 . 1 5} \mathrm{K}$ : enthalpy of interaction of the hydrocarbon, amide, and hydroxyl functional groups in dilute aqueous solutions. J. Solution Chem. 5, 733-750 (1976)

46. Hepler, L.: Thermal expansion and structure in water and aqueous solutions. Can. J. Chem. 47, 46134617 (1969)

47. Millero, F.J.: In: Horne, R.A. (ed.) Structure and Transport Processes in Water and Aqueous Solutions, Chap. 15, p. 622. Wiley, New York (1971)

48. Millero, F.J., Antonio, L.S., Charles, S.: The apparent molal volumes and adiabatic compressibilities of aqueous amino acids at 298.15 K. J. Phys. Chem. 82, 784-792 (1978) 
49. Lark, B.S., Patyar, P., Banipal, T.S.: Temperature effect on the viscosity and heat capacity behaviour of some amino acids in water and aqueous magnesium chloride solutions. J. Chem. Thermodyn. 39, 344-360 (2007)

50. Parke, S.A., Birch, G.G., Dijk, R.: Some taste molecules and their solution properties. Chem. Senses 24(3), 271-279 (1999)

51. Shamil, S., Birch, G.G., Mathlouthi, M., Clifford, M.N.: Apparent molar volumes and taste of molecules with more than one sapophore. Chem. Senses 12(2), 397-409 (1987)

52. Belitz, H.D., Chen, W., Jugel H., Treleano, R., Wieser, H., Gasteiger J., Marsili, M.: Sweet and bitter compounds: structure and taste relationship, Chap. 4. In: Boudreau, J.C. (ed.) Food Taste Chemistry. American Chemical Society Symposium Series, vol. 115, pp. 93-131. American Chemical Society (1979) 